\title{
Ércföldtan Magyarországon a Földtani Közlöny 150 évének tükrében
}

\author{
FÖLDESSY János ${ }^{1}$, MOLNÁR Ferenc ${ }^{2}$, BIRÓ Lóránt ${ }^{3}$ \\ ${ }^{1}$ Miskolci Egyetem, Mũszaki Földtudományi Kar, Ásványtani-Földtani Intézet, foldj@uni-miskolc.hu \\ ${ }^{2}$ Finn Földtani Szolgálat, Espoo, Finnország, ferenc.molnar@gtk.fi \\ ${ }^{3}$ Eötvös Loránd Tudományegyetem, Természettudományi Kar, Földrajz- és Földtudományi Intézet, Általános és Alkalmazott Földtani Tanszék, \\ birolorant@caesar.elte.hu
}

\section{Ore geology in Hungary as represented by publications in the Földtani Közlöny over the past 150 years}

\begin{abstract}
This review has been prepared to celebrate the 150th anniversary of the first publication of the Földtani Közlöny (Bulletin of the Hungarian Geological Association) journal. The scope of the review covers the most important results of ore geological research in the light of relevant publications of presented in this journal. As the borders of the Hungarian state have been changed several times over the past 150 years, the geographical area referred to in the respective publications has also varied: from the larger historic Hungary (between 1870 and 1919) to the Hungarian state as it is known today. Thus the timeline in this review has been divided into several periods in order to follow changes in the mineral policy of Hungary according to the nature and size of Hungary and its concomitant economic structure: namely, 1870-1919 (until the end of the WW1), 19191945 (restructuration), 1945-1993 (state planned economy), and 1993- until today (transition to market economy). Within these periods, the respective geographic locations and geological activities have been grouped under the name of the major geographical/geological domains. The recent valid names of localities and activities have been used to make it easier to find their location on modern maps. In the case of places which are now outside of the current borders of Hungary, the former Hungarian names and the currently used local names have been given. Only in instances where it seemed to be inevitable have publications not included in the Földtani Közlöny been referred to. Due to the great abundance of information and the limits of the length of a journal article, only 1-2 sentences have been dedicated to (even very important) published articles. A further compromise involved the use of a very restricted number of graphics. With reference to this, it was decided that changes in the related knowledge (as well as the interpretations connected with that knowledge) would be illustrated by the maps and profiles of important ore deposits from the different periods of time. This review highlights the names of some of the outstanding professionals who were the main contributors to the relevant science in the given period. All selections are subjective and reflect the personal views of the authors. These authors represent three generations of ore geologists who have worked, or are currently working in Hungary.
\end{abstract}

Keywords: ore geology, ore deposits, mineral exploration, history, collection of publications

Összefoglalás

Áttekintésünk a Földtani Közlöny megszületésének 150. évfordulójára készült. Célja, hogy a folyóiratban megjelent közleményekből felépítve adjon összegzést a hazai ércföldtan eredményeirôl. Áttekintettük az összes, a Közlöny hasábjain megjelent közleményt, s ebből választottuk ki azokat, amelyek valamilyen szempontból jelentős ércföldtani információt tartalmaznak. Úgy változtattuk az áttekintésünk területi merítését, ahogy az ország határai változtak, a történelmi Magyarországra és a mai határainkon belül eső területekre. Az időszakot a politika és történelem diktálta szakaszokra tagoltuk, amelyek egyúttal az állam gazdasági struktúrájában, ezen belül ásványvagyon-politikájában fellépő változásokat is tükrözték. A mai országhatáron kívül esố területeken lévő lelőhelyek esetében a magyar név mellett a ma érvényes helységneveket is feltüntettük. Az információbőség és a terjedelmi korlát kettős szorítása miatt egy-egy (még olyan fontos) lelőhely említésére is csak egy-két mondatot fordíthattunk. Az ábrák pár legfontosabbnak ítélt telepegyüttes földtani térképe, szelvénye és teleptani modellje révén mutatják be az ismeretek bővülését és az értelmezés fejlődését. Néhány általunk legjelentősebbnek vélt olyan személy nevét is kiemeltük az egyes időszakokban, akik véleményünk szerint a legfontosabb alakítói voltak a mindenkori szakmai tudásunknak. A válogatásunk szubjektív, amit a ma aktív szakemberek három generációját képviseló társszerzőcsapat önellenőrző képessége útján reméltünk kordában tartani. 


\section{Bevezetés}

A Földtani Közlöny szerkesztőinek megtisztelő kérésére vállalkoztunk arra a szinte lehetetlen feladatra, hogy korlátos terjedelemben foglaljuk össze az elmúlt 150 év legjelentősebb ércföldtani eredményeit a Kárpát-Pannontérségben, javarészt, de nem kizárólagosan a Földtani Közlönyben megjelent információkra támaszkodva.

Másfél évszázad jelentôs időtávlat egy szakmai folyóirat történetében. Ezt az idôt a külsô történelmi környezet diktálta szakaszokra tagoltuk, amelyek egyúttal éles területi és gazdaságstratégiai változásokat is takarnak. Az első szakaszt 1870-1919 közé tettük. Ebben a szakaszban a kiegyezést követő országhatárok közötti előfordulások információit foglaltuk össze. A későbbi időszakokban csak a mai Magyarország területén lévő ércelőfordulásokkal kapcsolatos eredményeket követtük. A második, 1920-1945 közötti szakaszt a megmaradt magyar nyersanyagforrások újraértékelése és a hadigazdálkodás stratégiája jellemezte. A harmadik szakasz, 1946-1993 között, a központi tervgazdálkodástól vezetett a piacgazdaság ismételt feltalálásáig. A negyedik szakasz 1994-től máig tart, és a magyar ércföldtan küzdelmét mutatja be a kinyíló globális gazdasági térben és a piacgazdaságra való átállás tükrében.

Az ércelőfordulások története hosszú, túlnyúlik még a Közlöny 150 évén is. A legjelentősebb ércelőfordulások akár minden időszakban ismételten előtérbe kerültek, a tudományos és gyakorlati kutatások eltérő mérföldköveit jelezve. Csak a legfontosabb eredmények említését engedte a terjedelmi korlát, így számos kisebb jelentôségú vagy kevés nyilvánosságot kapott kutatási eredmény kimaradt az összeállításunkból.

Célunk a tudományágunk tükröződésének bemutatása volt a Közlönyben nyilvánosságot kapott tanulmányokon keresztül. Más forrásokat akkor vettünk igénybe, ha egykor vagy ma jelentősnek gondolt, feltétlenül említendő hazai előfordulásokról ércteleptani munkák a Közlöny cikkanyagából hiányoznak.

A számos szerző és szakember közül kiemeltünk minden korszakban néhány olyan nevet, akik véleményünk szerint a mérföldkövek állításához a legnagyobb mértékben járultak hozzá. Közöttük vannak az egyetemi, akadémiai szektor kutatói, a gyakorlati nyersanyagkutató szakemberek és a stratégiát formáló intézményvezetők.

Mint a cím is mutatja, csak az érces ásványi nyersanyagokkal foglalkoztunk. A bauxitól és az ipari ásványokról külön értékelések készülnek. Számos ércásvány ásványtani, kristálytani leírása is szerepel a Közlöny cikkanyagában. Ezeket ásványtani közlésként értelmeztük, és csak akkor tértünk ki rájuk, ha az információ jelentôs teleptani következtetést is tartalmazott.

Válogatásunk szubjektív. Az idő rövidsége és a téma nagysága kettős szorításában több komoly projekt biztosan kihullott a nagylyukú rostán. Ezúton kérünk mindenkitől elnézést, akik más, talán jobb válogatást javasoltak volna.

\section{A kiegyezéstốl az I. világháború végéig 1870-1919}

A Monarchia Magyarországának megkésett, de sikeres ipari forradalma a nyersanyagkutató és -termelő gazdasági ágazat felpezsdülését is eredményezte. A Földtani Közlöny elsố évfolyama ebben a fellendülési idôszakban jelent meg. Az adott korszakban főként az országot keretező kárpáti hegykoszorúban található hagyományos érces provinciák (Selmeci- hegység, Szepes-Gömöri-érchegység, Gutin és az Erdélyi-érchegység, Bihar-hegység, Bánát, Cibles, Fruska Gora) kutatási eredményeiról számoltak be a tudományos értekezések. A mai határainkon belüli már akkor is ismert, múködő vagy kutatott előfordulásokról írt dolgozatok viszont ritkán jelentek meg a Közlönyben.

A folyóiratban publikáló szerzők közül a korszak egyik leghíresebb, gyakorlatot és elméletet is egyaránt múvelő kutatója volt SzABó József geológusprofesszor, aki több ércelőfordulás területéről földtani, kőzettani, szerkezettani megfigyeléseit összegző értekezést írt ebben az időszakban. Személye híd a tudományunk bölcsőjének tekinthető selmeci Bányászati Akadémia (melynek végzett hallgatója volt) és a budapesti egyetem (a későbbi Eötvös Loránd Tudományegyetem — ELTE) között (amelynek elsố geológusprofesszora lett). MADERSPACH Lívius bányamérnök neve a Felvidék előfordulásaihoz (a Közlöny anyagában Pelsőcardó) és Rudabányához kapcsolódott. A közlemények alapján jól követhető PÁLFY Móric geológus kiemelkedő ércföldtani munkásságának felívelése, mely az erdélyi előfordulások részletes tanulmányozásával kezdődött.

\section{Ércképzôdési elméletek és kutatási módszerek}

PÁLFY (1916) az eruptív kőzetek zöldkövesedése tárgyú értekezésében a szárazföldi vulkáni-hidrotermális (a mai értelemben vett epitermális) kőzetelváltozási zónásság ércgenetikai modelljének első hazai építőjeként említhető. Részletes, a megjelenés idejében valószínúleg nagyon korszerû áttekintő cikk köthető CzECK (1912) nevéhez a radioaktivitás jelenségérôl. Az új fizikai felfedezés földtani, geofizikai kapcsolódásait mutatja be a radioaktív gyógyvizek (pl. Pöstyén) kiemelésével.

\section{Bánát, Erdélyi-érchegység és Bihar (Banat, Bihor)}

A Bánát ércprovinciájáról egyedül SzABó (1875a) trachytokról szóló részletes leírása említhető. Az erdélyi Arany-négyszög súlyához méltóan számos értekezésben jelent meg. A római kori bányászati és földtani kapcsolódású régészeti anyag feldolgozását TÉGLÁs (1893) közleménye képviselte, átfogó képet adva ennek a ma is nagy jelentőségú érces provinciának a Római Birodalom történetében elfoglalt komoly szerepéról. WINKLER (1871) a verespataki (Rosia Montana) bányászat állapotáról és folyó feladatairól adott beszámolót, KREMNITZKY (1888) az ércképződési megfigyeléseket összegezte, PÁLFY (1905) az ércesedéseket befogadó kőzetek kőzettani és földtani eszközökkel tisztáz- 
ható korviszonyait ismertette. FRANZENAU (1892) beszámolt a Brád (Brad) környéki akkori nagy aranykutatási eredményekrôl. PAPP $(1908,1911)$ Almásszelistye (Almaş-Sălişte) és Godinesd (Godineşti) ércesedését írta le. BÁNYAI (1919a) részletes leírást jelentetett meg Offenbánya (Baia de Arieş) ércesedésérôl, az aranyérces telérek anyagát ráeső fényú optikai mikroszkópia alkalmazásával vizsgálva (BÁNYAI 1919b) A Bihar-hegységi Rézbánya (Băița) az ércásványtani meghatározásokkal és elemzésekkel kapcsolatban került a Közlöny lapjaira részben SzABó (1876), részben Lőw (1908) értekezéseiben. INKEY (1879) az érctelérek mellékkőzeteiről adott új adatokat.

\section{Gutin, Cibles, Lápos}

KocH (1880) részletes kőzettani vizsgálatokról számolt be Cibles (Munții Țibleş) és Láposbánya (Baita) zöldkövesedett andezitjében. Kazanesd (Cazanesti) pirittelepeirôl két közlemény látott napvilágot LACKNER (1904, 1906) tollából. RozLOZSNIK (1919) Erdély Macskamezó (Răzoare)-típusú vas-mangánérc előfordulásainak eredetéről értekezett. A tanulmány a teljes kárpáti hegykoszorú összes akkor ismert hasonló lelőhelyének közös tulajdonságait egy egységes — üledékes-metamorf — képződési modellbe foglalta össze, az ércföldtani modellalkotás elsố hazai példájaként. A nagybányai (Baia Mare) Veresvíz aranyérc teléreiről írt rövid bányaföldtani tartalmú közleményt SzoKoL (1896).

Szepes-Gömöri-érchegység (Spišsko-gemerské Rudohorie)

A nagyszámú ismert és múködő lelőhely ellenére a terület ércföldtanának kutatási eredményei nem jelentek meg a Közlönyben. Csupán egy előfordulás, a Sziliceifennsík határára esô Pelsốcardó (Ardovo) Pb-Zn-előfordulásának földtani és bányászati jellemzését találtuk MADERSPACH (1877), illetve STÜRZENBAUM (1879) tollából. A máig vitatott keletkezésû előfordulás anyaga az ún. gálmaércek közé tartozik (uralkodóan smithsonit összetételü cinkérc).

\section{Selmeci-hegység}

(Štiavnické vrchy)

Talán a Bányászati Akadémia szomszédsága révén, de a legteljesebb szakirodalmi anyag a Selmeci-hegység előfordulásairól született. PRATZER (1871) értekezett az érctelérek földtani viszonyairól. CSEH $(1886,1890)$ két jelentős altáró bányaföldtani szelvényezését ismertette. MARTINY (1888) a Vihnye (Vyhne) és Hodrus (Banska Hodrusa) közötti altáróban harántolt érctelérek jellegeirôl közölt értekezést. GESELL $(1884,1885)$ több jelentésben számolt be a hegység előfordulásain végzett bányaföldtani felvételezéseiről. Az alapos vájvégrajzok és vágatszelvények egyik tőle származó példáját mutatjuk be az 1. ábrán.

SzABó (1878) a magmás kőzetek petrográfiai jellemzését, majd később az ércteléreken végzett szerkezeti megfigyeléseit (SzABó 1891) közölte. BöcKH (1901) tollából olvashatunk értékelést az eruptív kôzetek korviszonyairól.

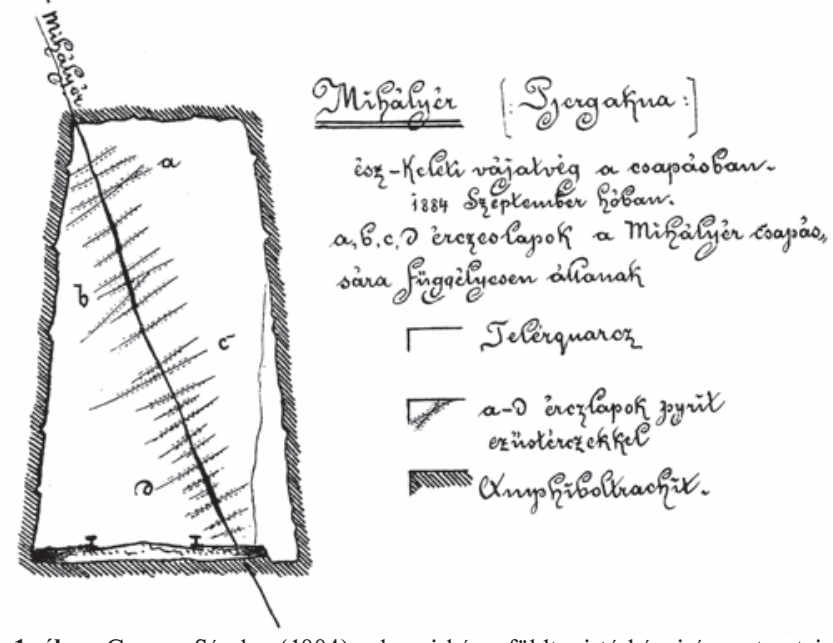

1. ábra. GESELL Sándor (1884) selmeci bányaföldtani térképei és metszetei tükrözik azt az aprólékos precizitást és szakmaiságot, amellyel generációja megvetette számos előfordulásunkon az ipari érctermelés földtani alapjait

Figure 1. The maps and sections compiled by Sándor GESELL (1884) reflect the high precision and accuracy, which was characteristic to that generation of geologists, with resulting fundamental findings and discoveries as geological basis of our industrial ore production

A Kárpát-medence belső területei (Mátra, Aggtelek-Rudabányai-hegység, Tokaji-hegység)

Ebben az időszakban kezdődött meg Recsken és Rudabányán a mai fogalmakkal is ipari méretűnek mondható érctermelés és feldolgozás. A rudabányai bányászatról a legkorábbi modern szakmai leírást MADERSPACH (1876) közölte, aki a lelőhely gazdasági potenciálját — még a nagyüzemi bányászat létrejötte előtt — igen jelentősnek vélte. A recski Lahóca elsô földtani közleménye a Közlöny elődjében (A Magyarhoni Földtani Társulat munkálatai) jelent meg KUBINYI (1867) munkájaként a termésréz előfordulásáról. Szintén a korai számok egyikében olvasható SzABó (1875b) közlése az enargit megjelenéséról. Két dolgozat is foglalkozik a szarvaskői wehrlit kőzettanával, kőzetkémiájával (SzABó 1877), illetve ércföldtanával (PÁLFY 1910), az akkori technológiák alapján az anyagot vasércként alkalmatlannak minősítve. Az egyik legrészletesebb feldolgozás a Tokaji-hegység északkeleti részén található egykori aranybányászati terület, Rudabányácska-Kovácsvágásról készült, mely egy egész füzetet megtöltött (SzÁDECZKY 1897).

\section{Magyarország Trianon után — pangás, újjáéledés, útkeresések — 1920-1945}

A történelmi Magyarország szétszakításával járó nemzeti trauma egyúttal hatalmas gazdasági feladatot is rótt az ország újjáélesztésére vállalkozókra. A negyedszázados fejlődési szakasz elejét a nagy emberveszteség és területi csonkulás, energiahordozó- és nyersanyagforrások elszakadása árnyékolta, amelyből a gyors lábraállás érdekében tett komoly erőfeszítések vezettek e rövid időszak végére egy kontinens méretekben ismét jelentőséget kapó ásványi- 
nyersanyag-termeléshez. Az itt most nem tárgyalt kőszén, kőolaj és földgáz kutatását, illetve a bauxit felfedezését nem említjük, bár megjegyzendő, hogy több esetben ezek vezettek el nagyobb mélységben, csak fúrásokkal feltárt érchordozó szerkezetek (pl. a Darnó-vonal) megismeréséhez. Az ország a Felvidék, Partium és Erdély nélkül szinte érctermelés nélkül maradt, az elsô világháború, illetve az azt követő események a még múködő lelőhelyek kimerüléséhez, leállásához is vezettek. Ez történt a RecskLahóca rézérc lelőhelyen is, mely végül az 1920-as évek második felében indult újra. 1921-től kezdődött Úrkút, majd 1928-tól Eplény mangánérctermelése. Az ország egyetlen megmaradt vasérctermelőjeként a háborút követően is tovább múködött Rudabánya, amely 1928-ban a külföldre szakadt korábbi cseh tulajdonosoktól a Salgótarján-Rimamurányi Rt. tulajdonába került.

Az összezsugorodott ország nem volt híján a földtani, bányászati szakértelemnek. A szinte kitermelhetô ércvagyon nélkül maradt gazdaságban a bányászat fejlesztésének igénye serkentőleg hatott az ércföldtani kutatásokra, főként a középkori ércbányászattal jellemzett ismert területeken (Mátra, Börzsöny, Tokaji-hegység). Ugyanekkor számos, a hagyományos bányavidékeken edződött szakember itt talált új otthonra. A Közlönyben is publikáló szakemberek közül kiemelve: PÁLFY Móric korai haláláig ércföldtani modelleket alkotott Recskról, Rudabányáról; RozLOzSNIK Pál szinte az összes érces területünk földtani alapjainak kidolgozásában jelentős szerepet kapott. Fiatal kutatóként a német iskolákban tovább csiszolódott SzTRÓKAY Kálmán (mineralógus, később professzor, ELTE) nevét kell megemlíteni, aki egyéb jelentős kutatások mellett a recski Lahóca ércparagenezisének meghatározásával járult hozzá az ércföldtani ismeretek bővítéséhez.

\section{Mecsek}

A két háború között Magyarország vasércbányászata Rudabányára korlátozódott, de a termelés a hazai ipar nyersanyagigényét nem elégítette ki. Ezért nagy reményeket keltett a mecseki magnetites ércdarabok előkerülése Magyaregregy környékén. SzTRóKAY (1941) részletes ásványtani, kőzettani és földtani megfigyelések alapján kimutatta a törmelékes üledékes környezet (ma Magyaregregyi Konglomerátum) ércdarabjainak kapcsolatát a kréta korú bázisos magmatizmussal.

\section{Bakony}

Az úrkúti oxidos mangánérctelepet eocén korú barnakőszén után kutatva MEINHARDT (1921) bányamérnök fedezte fel. Jelentôségét felismerve 1922-ben részvénytársaság alakult az érc kitermelésére a Deutsche Bank, a
Kohner és Fia Bankház és Zichy Béla földbirtokos részvételével. A vasas, oxidos mangánérc termelése 1925-ben külszíni múveléssel a Csárda-hegyen kezdődött. A kezdetleges technikai felszereltséggel induló külszíni múvelést az egyre erősödő gazdasági válság 1930-ban megbénította, majd az oxidos mangánérc termelése 1935-ben indult újra mélymúveléssel, az I. sz. akna (Szent István akna) területén. 1940-ben a II. akna és 1943-ban a III. akna mélyítése is megkezdődött, de ez utóbbit a tervezett szintig csak 1953ban mélyítették le (SzABó 2006).

\section{Börzsöny}

Különböző típusú lelőhelyekre vonatkozó ércmikroszkópos vizsgálati eredményeket bemutató cikkekben találhatók szemelvényes megfigyelések Börzsöny-hegységi ércmintákról (PAPP 1932, 1933).

\section{Duna-Dráva}

Felvetődött a több évszázados múltra visszatekintô folyami aranymosás ipari mértékú növelésének kérdése is. A Magyar Nemzeti Bank és a Pénzügyminisztérium megbízásából PANTó Dezső (1935) végzett ezirányú vizsgálatokat. A Duna, Dráva és a Mura egyes szakaszain jellemezte a torlatok aranytartalmát, az aranyszemcsék méretét és összetételét. Példaképpen a Győrszentiván mellett mintázott és mosással vizsgált arany koncentrációértékeit ábrázoló szelvényt mutatjuk be a 2. ábrán. Megállapítása szerint az előfordulásokra nagyüzemi termelést telepíteni akkor nem volt gazdaságos. Napjainkban azonban a melléktermékként való kinyerés lehetôsége többször ismételten felmerült.

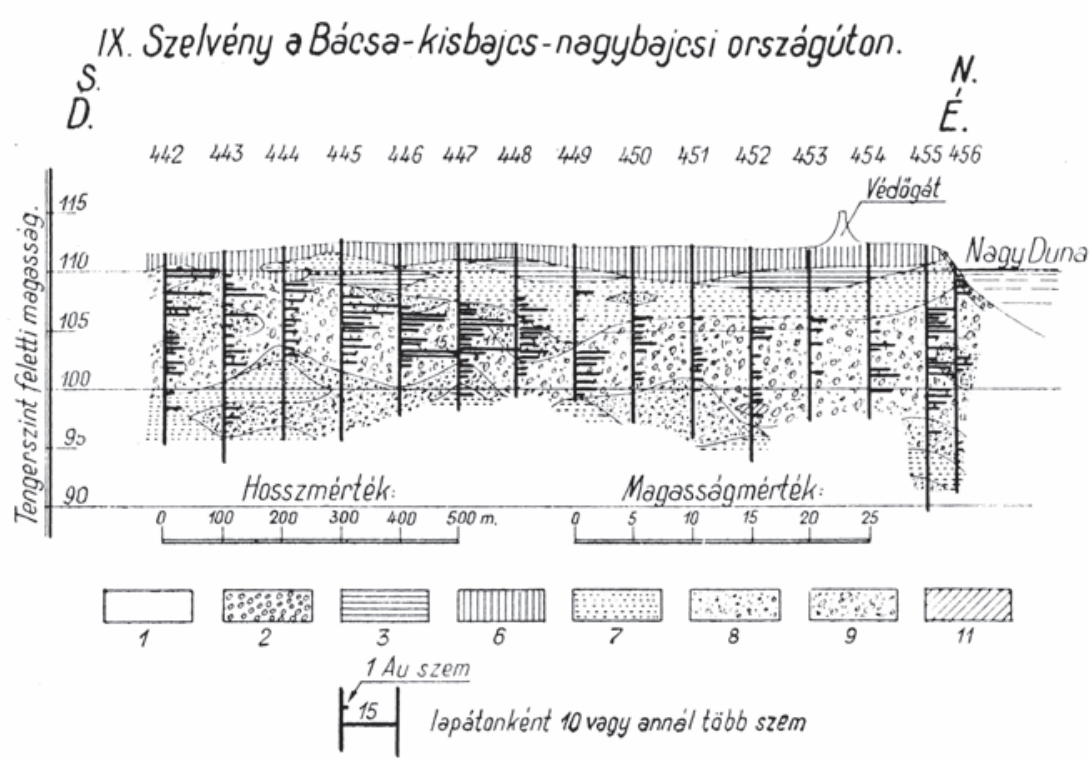

2. ábra. PANTó Dezső (1935) munkája máig egyedülálló, alapos dokumentációja a Duna, Dráva, Mura kavicsteraszaiban található torlatarany-dúsulások kutatásának. A teraszt kutatóaknákkal tárták fel, s az aknákban szelvényezték az üledékeket, illetve rendszeres mélységközökben mosták és szemcse/lapát mennyiségben adták meg az arany koncentrációját

Figure 2. Dezsö PANTó's (1935) work is a unique detailed documentation of the placer gold showings along the Danube, Drava, Mura rivers. The gravel bank was explored by shafts, in which the sediments were logged, sampled, and the concentration given in number of showings per shovel 


\section{Mátra}

A korábban már ismert, és múvelt recski ércelőfordulások jelentőségének megnövekedésével a Mátra egyéb területeinek továbbkutatása is megélénkült. Az ebben az időszakban a recski Lahócán és környezetében felhalmozott ércföldtani ismertek és bányászati tapasztalatok a második világháborút követő kiterjedt kutatás és bányászat alapjait rakták le. A két világégés közötti időszakra esett a Gyöngyösoroszi ércbányászat fejlesztési lehetőségeinek újravizsgálata is: az Urikány-Zsilvölgyi Részvénytársaság érckutatási kirendeltsége 1926-ban nyitotta újra a Károly-tárót. A kezdeti lendület - a kedvezőtlen gazdaságossági tényezők miatt — azonban megtört, és 1931-ben a kutatási-bányászati tevékenység leállt a gyöngyösoroszi érces területen. A mátrai ércelőfordulások átfogó ismertetését a Földtani Közlöny hasábjain Löw (1925) jelentette meg. Munkájában az ércesedéseket három csoportban, a Parád és Recsk közé esố területen, a gyöngyösoroszi területen, és a báj-pataki érces területen mutatta be. Érdekesség, hogy még a modern ércföldtani modelleknek is jól megfelelően, a lahócai ércesedést Butte (Montana) és Bor (Szerbia) enargitos ércesedésével hasonlította össze, és kiemelte, hogy az amerikai területen egészen 900 méteres mélységig követte az ércesedést a bányászat. Ez a későbbi recski kutatások tükrében igencsak előremutató megállapításnak bizonyult. A „mátrabányai” (lahócai) ércesedés részletesebb leírását az enargitos érc nagy aranytartalmát bizonyító új elemzési adatokkal és a kőzetátalakulási jelenségek bemutatásával, továbbá a bányászat továbbfejlesztési lehetôségeinek taglalásával VITÁLIS (1926) közölte. A lahócai bányászat felfutásával a bányaföldtani viszonyok és az ércesedés ásványtani és minőségi-mennyiségi jellemzőinek pontosításában PÁLFY Mórnak, RoZlozSNIK Pálnak és SZTRÓKAY Kálmánnak az adott időszakban folytatott munkássága máig is mérvadó, de eredményeiket nem a Földtani Közlönyben publikálták.

\section{A vas és acél országától az új gazdasági mechanizmuson át a piacgazdaságig 1946-1993}

A háború befejeződése utáni újabb gyökeres politikai és gazdasági fordulat ismét az ország nyersanyag-stratégiájának újragondolását követelte. A háború utáni újjáépítés óriási nyersanyag- és energiaigényén túl a jóvátételi kötelezettségek, illetve a szocializmust építő ország erôs nehézipari és hadiipari irányultsága az ásványinyersanyagforrások erőltetett menetben történő felderítését és fejlesztését kényszerítette ki. A gyors felfutás magával hozta az elkapkodott gazdasági és szakmai értékeléseket, valamint az ezzel járó gazdasági és technikai nehézségeket is. Ebből fakadt az a máig élő előítélet, amely szerint az ország területén már nincsenek gazdaságos érces lelőhely felderítésére és kitermelésére alkalmas dúsult környezetek. Az előítéletet élesen cáfolta Recsk, ahol az 1960-as évek végén felfedezték a mélyszinti ércesedést. Megítélésünk szerint talán ez és az ezt követô évtized volt a csúcspont, s innen lejtmenet vezet a korszakzáró, s egyúttal a piaci viszonyokat leíró új bányatörvény elfogadását adó 1993-as évig.

A jelen felé közeledve a jelentős szakemberekre való emlékezés is élesebb. Az elméletépítők között érdemel említést SzÁDECZKY-KARDOSS Elemér a különféle érctípusok geokémiájának részletes vizsgálatával, illetve az elsó (és talán máig egyetlen) magyar nyelvú geokémiai kézikönyv írójaként. GRASSELY Gyula Szegeden épített új ércföldtani iskolát a mangánércek vizsgálata köré összpontosítva. SzABÓNÉ DRUBINA Magda a mangánércek földtanának feldolgozásáról elsőként jelentetett meg rangos tanulmányt nemzetközi folyóiratban. SzTRÓKAY Kálmán és KocH Sándor az ércelőfordulások ásványtana területén alapozta meg legjelentősebb előfordulásaink paragenetikai ismereteit. SZÉKYNÉ FuX Vilma és HERMANN Margit a mátrai és tokaji vulkanitokban észlelt kálimetaszomatózis vizsgálata terén alkotott maradandót.

Neves terepi geológusok rakták le bányászott ércelőfordulásaink földtani alapjait, e téren PANTó Gábor nevét kell elsôként említeni. KIss János az ásványtan és teleptan széles eszköztárával vizsgált több ércelőfordulást, és az egyetemi oktatásban mind a mai napig használt Ércteleptan I-II. tankönyvével jelentősen hozzájárult a hazai szakemberképzéshez (KISS 1982). ZELENKA Tibor több területen fektette le a hazai ércföldtani ismeretek alapjait, s a kritikus időszakban sikerrel vezette a recski kutatásokat. BARABÁs Andor az uránérckutatás és termelés földtani irányításában szerzett jelentős, irodalmi tevékenységén is túlmutató érdemeket. Végül MorvaI Gusztáv nevét érdemes kiemelni, aki állami szervezet egyik vezetőjeként volt képes az érckutatások, ércföldtan számára a szükséges forrásokat számos egyéb céllal versenyeztetve folyamatosan biztosítani.

$\mathrm{Az}$ ország ércföldtana szempontjából nagyon fontos történetet további kisebb szakaszokra tagoltuk.

\section{A nyersanyag-ellátási alapok újrateremtése 1946-1960}

Talán soha nem volt, és mégegyszer nem lesz olyan másfél évtized, amikor az ország érces lelőhelyeivel kapcsolatban annyi új kutatási eredmény és ezek bányászati megvalósítása született volna, mint ebben az időszakban. Egy sor régi, 1945 előtt is múködő lelőhely megújult és újranyílt (Recsk-Lahóca, Rudabánya, Úrkút), másrészt korábban nem termelő, kevésbé ismert előfordulásokon került sor új bányanyitásra (Szabadbattyán, Pátka, Gyöngyösoroszi, Kővágószőlős), illetve jelentôs, fôként bányászati módszerrel folytatott kutatásokra (Telkibánya, Nagybörzsöny). A megvalósult bányanyitásokat több esetben elsietett politikai döntésre, és nem megalapozott kutatásokra támaszkodó gazdasági becslésekre alapozták, az ezzel együtt járó állandósult múködési nehézségeket is előidézve.

Ez volt az az időszak is, amikor a két háború között, illetve a második világháborút követő időszakban végzett szakemberek elsố generációja a legaktívabb időszakában volt. A tudományos közlemények sorában mindez kevéssé tükröződött, mivel az ásványvagyonok és ehhez kapcsolódó 
bányászattal kapcsolatos információk ebben az időszakban a legtöbb esetben szigorú minősítésú vállalati vagy államtitkot képeztek. A pozitív folyamat menetében súlyos törést, szakemberveszteséget jelentett az 1956-os forradalom leverése utáni tömeges emigráció.

\section{Mecsek}

A kôvágószőlősi urániumérc-előfordulás felfedezéséről nincs korabeli nyilvános hír. Ezért az indulás időszakát késóbbi visszaemlékezésekből idézzük. Az 1953-ban szovjet geofizikus expedíció által felfedezett (BARABÁs 1997), a jakab-hegyi permi homokkő összletben létrejött ércesedés elsố bányászati feltárásai 1956-ban készültek el, a termelés 1958-ban indult meg Bauxit Vállalat fedônéven. A termelés megindulásával párhuzamosan részletes lelőhelyi kutatás kezdődött és folyt több évtizedig, erről WéBER (1997) számolt be. A kutatásban, illetve az érctermelés minőségbiztosítása terén jelentős operatív szerepet kaptak a geofizikai módszerek (BARANYI et al. 1997). Az egész országra kiterjedő felderítô uránérckutatások újabb jelentős gazdasági súlyú előfordulást nem, számos egyéb ércelőfordulást viszont „melléktermékként” felderítettek (MAJOROs 1997). Az első nyilvános tudományos ásványtani közlés a legkorábbi időkből KIss (1960) munkája, az ércesedéshez kapcsolódó krómcsillám- és vanádiumdúsulás vizsgálatáról.

\section{Bakony és Keszthelyi-hegység}

A vasérchez adalékolt mangán ötvözőfém ércét termelő úrkúti és eplényi ércbányák, a háború után államosításra kerülve, a felújított kutatások után folytatták az érctermelést (KuN 1989). Jelentős eredmény volt a karbonátos mangánércek felismerése, melyek kialakulását elsőként NoSZKY \& SIKABONYI (1953) ismertette. SIDÓ \& SiKABONYI (1953) a tengeri üledékes eredet alátámasztását szolgáló paleontológiai értekezést közölt. Az úrkúti mangánérc képződéséről a kor szellemének és személyes pozíciójának megfelelő szemszögú dialektikus értelmezés született VADÁsz (1953) tollából. SzABÓNÉ DRUBINA (1959a) foglalta össze az eplényi ércelőfordulás földtani viszonyait. Szintén az ő tollából származik a magyar mangánérc-előfordulások rangos nemzetközi folyóiratban megjelent átfogó jellemzése (SzABÓNÉ DRUBINA 1959b). Ipari geológusként a gyakorlati szempontok kiemelésével taglalta az úrkúti előfordulás földtani értelmezését CSEH NÉMETH (1958). Cserszegtomajon a pannóniai rétegekben előforduló pirit-markazit előfordulásáról közölt adatokat PAPP \& PoJjÁK (1948). SzEnTES (1948) ugyanezen vas-szulfid előfordulások földtani viszonyairól írt jelentést. KISS \&VIRÁGH (1959) a pécselyi U-tartalmú foszfátos üledékes képződményekről közölt elsôként információt.

\section{Velencei-hegység}

Az ismert gránitos terület érctelér-előfordulásain már az időszak legelején felszíni és bányászati feltáró munkák kezdődtek nyolc területen Pátka, Pákozd térségében. Ezekből több kis, föld alatti bányaüzemet nyitottak előzetes fúrásos kutatások nélkül. $\mathrm{Az}$ üzemek $\mathrm{Pb}-\mathrm{Zn}$ és fluorit ércek termelését célozták meg. KISS (1951) részletes leírását adta a szabadbattyáni ólomérc-előfordulásnak, mely 1950-1954 között föld alatti termelő üzemként múködött. FöLDVÁRI (1947a, b) a molibdéndúsulások földtani viszonyait vizsgálta, a velencei mélyfúrás anyagát dokumentálta. JANTSKY (1957) mintegy tízéves térképező tevékenysége eredményeként állította össze a hegység földtani monográfiáját. KuBOVICS (1956) az ércesedési terület talajgeokémiai vizsgálatának első adatait közölte. A Meleg-hegy hidrotermális ércesedését bemutatva jelezte az aranydúsulás létét, és az a hegység keleti részén előfoduló andezites vulkanizmushoz kapcsolódó vulkáni breccsákkal való genetikai kapcsolatot valószínúsítette (KuBOvics 1958). A gránitpegmatitok magas Sc- és Nb-tartalmáról megjelent akkori közlése (KUBOvics 1960) a legújabb időkben nyert gazdasági értelmet az említett elemek kiemelkedő stratégiai fontossága révén. A pátka-kőrakás-hegyi érckutatási eredményeket értékelve KASZANITZKY (1959a) az ércesedést genetikailag szintén a gránitot áttörô andezites vulkanizmushoz kapcsolta.

\section{Börzsöny}

Nagybörzsöny kutatását 1946-ban kezdte újra az állami ércbányászat a régi Rózsa-, Ludmilla-, Fagyosasszonytárók újranyitásával. Az érces indikációk alapján 100 m mélyen, a régi múveletek alatt $2 \mathrm{~km}$ altárót hajtottak ki, érdemleges ércesedést azonban nem találtak. Az akkori csak vágathajtással végzett — kutatások 1956-ban fejeződtek be (Kun 1989). KocH \& GRASSELly (1952) foglalta össze Nagybörzsöny érces ásványegyüttesét. Ugyanerről a lelőhelyről további részletes, az agyagásványokra összpontosító ásványtani tanulmány is született ERDÉLYI et al. (1957) tollából. A Királyrét környékén előforduló vasas képződmények földtani viszonyait LENGYEL (1957) ismertette.

PANTÓ GÁBOR (1949) a bejárható lelőhelyek felszíni környezetének és vágatainak földtani felvételét készítette el. Nagy alapossággal végzett bányavágat-szelvényezésére példa az a részletes rajz, amit ebben a tanulmányban az AlsóRózsa-táró aknatér faláról tett közzé (3. ábra).

$200^{\circ}$

$20^{\circ}$

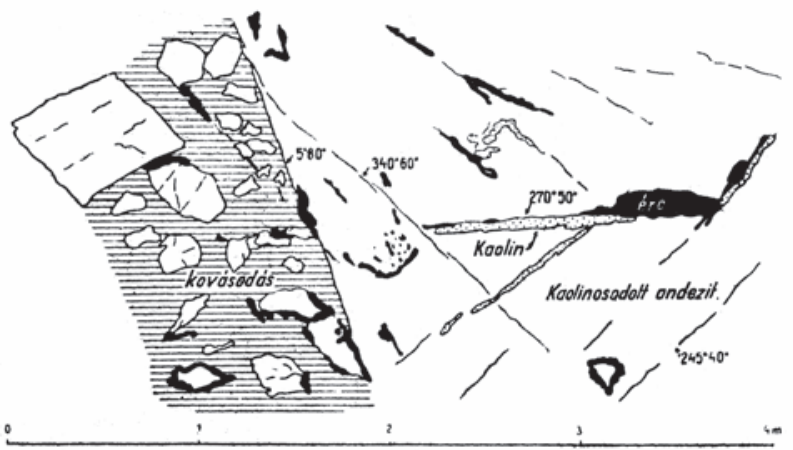

3. ábra. PANTó Gábor (1949) számos ismert ércelőfordulásunkon dolgozott, máig jól használható részletes bányaföldtani megfigyeléseket tett. Itt bemutatott ábrája a Nagybörzsöny színesfém-Au-Ag dúsulást feltáró egyik tárójában felvett földtani szelvényt ábrázolja

Figure 3. Gábor PANTó (1949) was an outstanding professional geologist, worked in a number of ore mines, carrying out underground mine mapping. This section shows a mapped section of an adit in Nagybörzsöny base metal-gold-silver occurrence 


\section{Mátra}

A korábbi érckutatások jogainak megvásárlása után, 1949-ben indult a gyöngyösoroszi bányaüzem kiépítése, 1952-tôl pedig a föld alatti bányában megindul az ólomcinkérc termelése érdemleges érckutatási előzmények és feldolgozó üzem nélkül, aminek hátrányos következményei a bánya teljes életét végigkísérték (Kun 1989). PANTó (1953) mérte fel az épülő bánya földtani viszonyait Gyöngyösoroszi térségében. Kiss (1964) a Közép-Mátra ércesedésének ásványparagenezisét vizsgálta, és társszerzőkkel (KIss et al. 1966) a képződési hőmérsékletet stabilizotóp-vizsgálatok alapján becsülte. KASZANITZKY (1959b) összegezte genetikai értelmezését a Nyugat-Mátra ércesedésével kapcsolatban. A recski Lahóca rézércbányászata a háborús évek erőltetett termelése után négy évre leállt, majd az id. GAGYIPÁLFFY András által vezetett részletes bányabeli kutatások után 1950-ben indult újra. A rézércvagyon földtani értelmezését és értékelését PANTó (1951, 1952) készítette el. KIss (1958) kiterjesztette az ércföldtani vizsgálatokat a Darnóvonal keleti szárnyára. JANTSKY (1953) egy tőle viszonylag idegen témáról, a demjéni mangánércről közölt információt.

\section{Aggtelek-Rudabányai-hegység}

Rudabánya vált az ország nehéziparát ellátó vasércbányászat zászlóshajójává. Az érctermelés részben külfejtéses, majd döntően föld alatti módszerekkel folyt. Közben a földtani szakemberek igyekeztek a további termelés nyersanyagvagyon-hátterét kutatásokkal biztosítani. A hegység földtanáról szóló összefoglalását BALOGH \& PANTÓ (1953) ismertette. Az előfordulásról a történelem, földtan, bányászat, ércelőkészítés teljes vertikumát felölelő monográfiát állítottak össze az ott dolgozó geológus, bányamérnök, történész szakemberek (PANTÓ 1957). Jóval kisebb volumenú vasércbányászat folyt időszakosan Tornaszentandráson 1925-1951, illetve Martonyiban 1945-1952 között (Kun 1989).

\section{Tokaji-hegység}

Megkezdődött a hegység ércelőfordulásainak újabb áttekintése. Miközben a telkibányai ércesedés feltárása érdekében jelentős, a nyilvánosság elől elzárt bányászati kutatások folytak SzÉKYNÉ FuX Vilma és SCHERF Emil földtani irányításával, szélesebb körú földtani felderítő kutatás is kezdődött. Telkibánya ércgenetikai értékelésének eredményeiről LENGYEL (1948) írt. HERMANN (1952) a telkibányai andezit és riolit részletes kőzettani leírását közölte. GöBEL (1956) a rudabányácskai Nagybányi-hegy földtani leírását adja. Hasonló információt közölt a mádi vasérc-előfordulásról PANTÓ (1948), melynek genetikáját KocH (1953) dolgozta fel. SCHRÉTER (1948a, b) valamint LIFFA (1953) a földtani térképezés eredményeiról számoltak be.

\section{Az érckutatások csúcsidószaka - 1961-1979}

Az 1956-os forradalom újabb szakmai és gazdasági átrendeződést hozott. Az egyik oldalon a bányászatot előkészítő, állami finanszírozású rendszeres földtani kutatások egyre nagyobb arányúak voltak, a másik oldalon viszont a szakemberveszteség, a kinyíló gazdasági kapukon beköszönô versenyhelyzet és az állami támogatások csökkenése egyre több hazai előfordulás létét kérdőjelezte meg. A kinyíló kapuk egyúttal a nemzetközi együttmúködés és tapasztalatcsere idejét is elhozták, s ennek dokumentumai a Közlönyben is megjelentek beszámolók, összehasonlító értékelések formájában.

A korszak kezdeteként 1961-et jelöltük meg, mert ekkor kezdődtek a később komoly sikerre vezetô mélyszinti, fúrásos rézérckutatások Recsken. Új felderító érckutatások indultak a Nyugat-Mátrában, a Börzsönyben, a Velenceihegységben is, de ezzel párhuzamosan leállították a Velencei-hegység termelő bányáit és a telkibányai kutatásokat. Ebben az időszakban mennyiségi csúcsteljesítményét érte el a rudabányai vasérc, a mecseki uránérc, a bakonyi mangánérc és a gyöngyösoroszi polimetallikus érc termelése.

Egyre több, a kutatások módszertanát érintő alapkutatási eredmény is született. A hazai és határon túli geofizikai vizsgálatok összegyúlt adatai alapján regionális szerkezetföldtani modellek készültek, pl. SCHEFFER (1963) munkájaként a Vardar-öv folytatódásáról a Kárpát-medence aljzatában. KISS (1963) az uránmigráció és az ércgenezis kapcsolatáról közölt értekezést. A baktériumok ércásványok oxidációjában játszott szerepének vizsgálatát az ELTE kutatói kezdték meg (SzOLNOKI \& BogNÁR 1965). A színképelemzési berendezések és értékelési eljárások fejlődése már lehetővé tette tiszta ásványpreparátumok — a magyarországi szfaleritminták — nyomelemeinek vizsgálatát (SÁMSONI 1966). NAGY (1970) a hazai hidrotermális szfaleritminták indiumtartalmát vizsgálta.

Fontos adatok kerültek napvilágra a hegységi területek légi-radiometriai felvételezése során. Ennek egyik összefoglalóját adta WÉBER (1975). CSEH NÉMETH (1979) bemutatta az ország érctelepeit és termelő egységeit, valamint távlati kutatási programot vázolt fel.

\section{Soproni-hegység}

Az egész országra kiterjedő hasadóanyag-kutatások melléktermékeként vált ismertté a hegység metamorf képződményeiben kialakult színesfém- és ritkaföldfémércesedés (FAZEKAS et al. 1975).

\section{Mecsek}

A mecseki uránérckutatás és -bányászat kibontakozását követően számos kutatási információ is nyilvánosságra került. BARABÁSNÉ STUHL (1973) közölte a nyugat-mecseki felsô-perm összlet üledékföldtani jellegei statisztikus értékelésének rétegtani és egyéb földtani eredményeit. VIRÁGH \& VINCZE (1967) egyrészt nyersanyagkutatóként, másrészt anyagvizsgálóként a redox viszonyok és az ásványi paragenezis összekapcsolásával értelmezték a mecseki uránérc felhalmozódását, kihangsúlyozva a többszakaszú, több forrásra épülő eredetet. BALLA (1967, 1973), illetve BALLA \& DUDKO (1972) a kőzetek színe és az uránércesedés közötti összefüggésről (azaz az oxidációs állapot változásáról), az ércesedés szerkezeti kapcsolatairól, illetve az elsődleges uránfelhalmozódásról értekezett. Egy másik 
munkájában a szerkezeti elemek és ércesedés kapcsolatát vizsgálva rámutatott az ércdúsulás uránkoncentráció maximumai és az alaphegységi törésrendszerek térbeli kapcsolatára (BALlA 1969). VIRÁGH \& SzOLNOKI (1970) mikrobiológiai kísérletekkel vizsgálták az urán mobilizációját kemoautotróf és szulfátredukáló baktériumok jelenlétében. Ugyancsak az erôs biogén hatás nyomait derítették fel kutatók a kénizotópok eloszlásának vizsgálata nyomán a mecseki uránércesedésben (VINCZE et al. 1970). BALLA \& DuDKo (1972) számolt be kutatási eredményeiről az uránáthalmozódás ércképződésben játszott szerepe tárgyában. VÁRSZEGI (1965) rövid közleménye egy karbonátos rézásvány-előfordulást mutatott be a mecseki Éger-völgy alsótriász rétegeiben. Ez a máig szinte ismeretlen, de nagy kiterjedésû üledékes rézérc-előfordulásról az elsô megjelent publikáció. VINCZE \& FAZEKAS (1979) vizsgálták az uránoxid-sor ásványainak kifejlődési típusait, valamint a mikroszkópi kőzetszöveti összkép és az ércesedés mikromorfológiájának vizsgálata alapján az autigén ásványosodás időbeliségét elemezték. BARABÁs (1979) ismertette a Nyugat-Mecsek perm formációit és földtani viszonyait. Kiemelte, hogy a bányákban szerzett geológiai tapasztalatok hasznosítása a külszíni kutatás eredményeinek értékelésénél kiemelt jelentőségú. VIRÁGH (1979) további földtani, genetikai következtetésekre jutott az uránércesedés vizsgálatában. Az addigi ismeretek rendszerezésével megkülönböztette a földtani kutatási objektumokat: fácieslépcsôket, ércesedési szinteket, érctesteket, ércmorfológiai elemeket, ércásványokat a szerzô megismerési szinteknek tekintette, és ezeknek megfelelően megfogalmazta az egyes kutatási lépcsốk követelményrendszerét. BODROGI (1979) bányászati szempontból rendszerezte az addigi ismereteket. $\mathrm{Az}$ ércesedés morfológiai szerkezete és a múvelési technológia kölcsönhatásaként létrehozott egy matematikai modellt.

\section{Bakony}

Teljes üzemben folyt a mangánérctermelés Úrkúton, és a leállítási munkák az eplényi bányaüzemben. A tudomány ilyenkor többnyire a háttérben maradt. CSEH NÉMETH (1967) közölt tanulmányt a két múködő mangánérctermelő, Úrkút és Eplény földtani viszonyainak összehasonlításáról. KovÁcs (1970) a ritkaföldfémeknek az oxidos mangánérc átmeneti övezetében való feldúsulásáról adott geokémiai információkat. SzABó (1979) az úrkúti mangánércesedés bányabeli és mélyfúrásos kutatásának eredményeként felvázolta a medence térrövidülésének modelljét. E szerint a telepet egy erôteljes ÉNy-DK-i kompressziós hatás érte.

\section{Velencei-hegység}

A pátka-szúzvári ércbánya és több kis, ehhez kapcsolódó lelőhely $\mathrm{Pb}-\mathrm{Zn}$ - és fluoritércet termelt. A szétaprózódott érctermelés egyúttal a gazdaságosság késóbbi lehetőségét is eltörölte (KuN 1989). Az ércbányászat és az előkészítő kutatások tapasztalatait adta közre MıKó (1964), s a gránitintrúzióhoz való genetikai kapcsolódást feltételezte. A fluoritércesedés esetében ásványtani vizsgálatok is készültek, melyek a magas hőmérsékletű keletkezést adatokkal támasztották alá (ÓDOR \& SzEREDAI 1964). NAGY (1969) a különféle, hidrotermális eredetûnek feltételezett ritkaelemeknek a gránit ásványaiban való feldúsulásának a területi eloszlását mutatta be. Egy késői visszatekintő monografikus összegzés, a pátka-szűzvári lelőhely adatainak feldolgozásával bányászati térmodellépítés készuilt az előfordulásról a kritikus elemek alapkutatási programja keretében (MOLNÁR 2014).

\section{Budai-hegység}

Rövid közleményként jelent meg a Budaörs környéki triász karbonátos képződményekben talált tórium- és ritkaföldfém-dúsulásokról szóló jelentés (WÉBER 1962), ami máig mélyebb földtani értelmezés nélkül maradt.

\section{Börzsöny}

A hegységben az áttekintő uránérckutatásokkal kapcsolatos légi radiometriai felvétellel kapcsolatban mért káliumeloszlás adatait közölte WÉBER et al. (1972b). SINGH (1974, 1975) számolt be a nagybörzsönyi szulfidos ércásványok elektron-mikroszondás vizsgálatáról, illetve a talajgeokémiai vizsgálatok eredményeinek értelmezéséről.

\section{Mátra}

A hegység feletti légi radiometriai mérések eredményeit tette közzé WÉBER \& GÉRESI (1970). A földtani képződmények áttekintő geokémiai vizsgálata első adatai NAGY (1971) munkája nyomán kerültek nyilvánosságra. A Lahóca réz- és aranyérctermelése a háború utáni kutatások eredményeként stabilizálódott, és a folyamatos bányászat egészen 1979-ig tartott (GAGYI-PÁLFFY ID.1975). A kitermelt ércvagyon pótlására a MÁFI által a recski rézércesedés környezetében 1961-ben megkezdett, majd az Országos Érc- és Ásványbányák által folytatott mélyszinti kutatások 1968-ra vezettek jól körvonalazható, gazdaságilag is jelentősnek ígérkező eredményre. Ennek summázataként készült el az első összefoglaló jelentés, majd az itt összegyújtött adatok további tömörítéseként a Földtani Közlöny 1975. évi különszáma, amely sok tekintetben ma is az egyetlen átfogó és részletes nyilvános adatközlés a lelőhelyrôl. A kutatások az akkori politikai vezetés egyetértésével és támogatásával folytak, erről tanúskodott FüLÖP (1975) bevezetője. A kutatás gazdasági irányítója, GAGYI-PÁLFFY ID. (1975) méltatta a lelőhely népgazdasági jelentőségét. Hasonlóan helyezte el a felfedezést a szakmai eredmények rendszerében DANK (1975). A lelóhely komplex szerkezeti-magmaföldtani helyzetét ZelEnKA (1975) jellemezte. SzALAY (1975) a recski kutatási terület szerkezetkutató geofizikai méréseit és azok eredményeit, valamint az előforduláson több módszerrel végzett felszíni geofizikai kutatások értelmezését foglalta össze. Az alaphegységi üledékes képződmények kutatási adatait F. JÁRÁNYI (1975) összegezte. A rétegvulkáni andezitösszlet jellemzését FöLDESSY (1975) végezte el. A mélyszinti szubvulkáni andezittest és telérei kőzettani jellemzését BAKSA (1975b) adta. CsILlAG (1975) a hidrotermális kôzetátalakulást jellemezte, és a szkarnos 
képződmények felismerése is az ő munkájához kapcsolódott. A fúrások geofizikai mérési eredményeit MoRVAI \& VIOLA (1975) közölte. Az átfogó ércgenetikai kép kialakítása CSEH NÉMETH (1975) nevéhez fúződik. Az ehhez szükséges ércföldtani adatokat mikroszkópi vizsgálatok alapján CsONGRÁDI (1975) foglalta össze. Gazdaságföldtani értékelést adott GAGYI-PÁlfFy IFJ. (1975). A recski mélyszint kutatása egyúttal további jelentôs információkat is hozott egyéb ércesedésekről. BAKSA (1975a) a Lahócával szomszédos területen a mélyszinti kutatások során felismert új enargitos-luzonitos ércesedést ismertette (késóbbiekben ez Lejtakna területként vált ismertté). A porfíros rézércesedés és a lahócai $\mathrm{Cu}-\mathrm{Au}-$ ércesedés térbeli kapcsolatainak illusztrálására egy késôbbi, 2008-ban publikált, újabb megfigyelésekkel kiegészített földtani térképet túztünk be (4. ábra).

ZELENKA (1977) bemutatta a korábbi évtizedekben Recsk-Parádsasvár térségében különböző kutatási módszerekkel nyert szerkezetföldtani eredményeket. Kiemelte a Darnó-öv meghatározó jelentőségét az ércesedés folyamatában. ZELENKA \& MARKó (1979) a recski mélyszinti ércesedés DK-i részének kutatási adatait (szelvényezés, mélyfúrás, vágathajtás, kutatóakna) mutatták be, valamint összegezték az ércesedés földtani-teleptani viszonyait. FÖLDESSY \& BAKSA (1979) a recski lejtaknai érctermelés minőségi és mennyiségi adatait hasonlította össze a fúrásos kutatás során nyert adatokkal. Ezek alapján megállapították a megbízhatósághoz szükséges adatsúrüséget.
A Közép-Mátra ércesedésének (Parádsasvár) kutatása és értékelése VARGA et al. (1975) monográfiájában, illetve az ennek alapját adó földtani térképsorozatában jelent meg. Időközben tovább folytatódott a Közép- és Nyugat-Mátra földtani kutatása. SiKLóssy (1977) foglalta össze a bányaföldtani munkájához kapcsolódó lényeges szerkezetföldtani megfigyeléseit. A Nyugat-Mátrában is domináns hidrotermális kőzetelváltozás, a kálimetaszomatózis és a kőzetképződés kapcsolatát vizsgálta KUBOVICs (1966). Elsőként került sor stabilizotóp-összetétel vizsgálata útján keletkezési hőmérséklet becslésére egy nyugat-mátrai érctelér anyagán (CORNIDES et al. 1966). Összehasonlító értékelés készült az oligocén korú demjéni mangánérc és hasonló korú más európai mangánércek földtani viszonyairól (MoLNÁR \& MORVAI 1961).

\section{Aggtelek-Rudabányai-hegység}

HERNYÁK (1977) szerkezetföldtani értelmezést adott a bányászat során gyújtött adatok alapján a rudabányai vasérclelőhelyről.

\section{Bükk hegység}

A Földtani Közlöny ebben az időszakban errôl a területről nem közölt új ércföldtani információt, habár jelentések alapján ismert, hogy az állami kutatóvállalatok, egyrészt a Mecseki Ércbánya Vállalat, másrészt az Országos Érc- és Ásványbányák több területen végzett — sok esetben

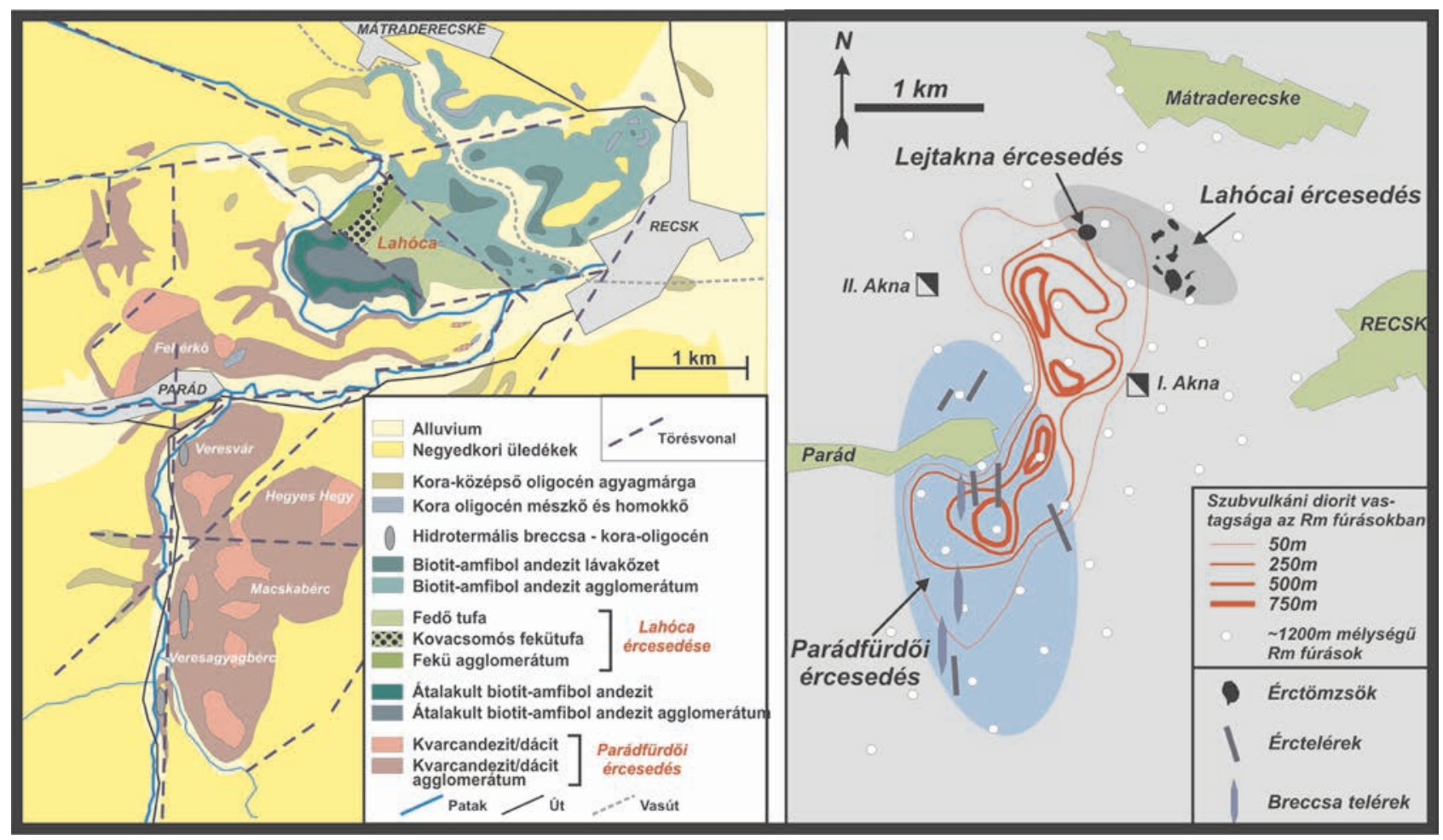

4. ábra. A recski érces terület földtani térképe és a felszíni epitermális ércesedések helyzete a szubvulkáni intrúziókhoz viszonyítva (MoLNÁR et al. 2008 nyomán). Az alaptérkép PANTÓ G. 1952-ben publikált térképének módosított változata, melyen a vetők helyzete ürfelvételek és árnyékolt domborzati térképek alapján került feltüntetésre. A szubvulkáni intrúzióknak a vastagsági térképe ZELENKA 1975-ben publikált munkájából származnak

Figure 4. The geological map of the Recsk ore complex, with the diagram showing the near-surface epithermal mineralzations compared to the subvolcanic intrusions. (MOLNÁR et al. 2008), modified after PANTÓ G. (1952). Faults are plotted using satellite imagery and relief maps. The thickness map of the subvolcanic intrusives is taken from ZELENKA 1975 
jelentős mennyiségű fúrás lemélyítésével — érckutatásokat.

\section{Tokaji-hegység}

Az uránérckutatásokkal kapcsolatos légi radiometriai felvétel káliumeloszlás-adatait közölte WÉBER \& GÉRESI (1972a). A MÁFI folytatta a hegység részletes földtani térképezését. E csoport tagjaként ILKEYNÉ PERLAKI (1961) a vulkáni kőzetek felszínközeli és mélységi hidrotermás elváltozásairól közölt értekezést. A bányászati kutatások összefoglaló értékelése során több tapasztalati megfigyelés született az egyes kôzetelváltozások (kaolinitesedés, propilitesedés és kálimetaszomatózis), illetve az ércesedés kapcsolatáról (SzÉKYNÉ FuX 1964, 1966). Jelentős hidrotermális ásványtársulásokról láttak napvilágot vizsgálati eredmények VARGÁNÉ MÁTHÉ (1961) részérôl a Sátoraljaújhely-Vágáshuta közötti aranyérc-indikációkról ismert területen.

\section{A piacgazdaság felé vezetó út kezdetei 1980-1993}

Az 1980-as évek felszínre hozták a központilag vezérelt hazai ásványinyersanyag-kutató és -termelő ipar felemás állapotát és felkészületlenségét a hazai gazdaságot minden irányból fokozatosan átszövő félpiaci, illetve piaci viszonyokra. A leginkább érintett szegmens a szénbányászatunk volt, amelynek átmenetét az új felfogású gazdálkodás irányába állami szervezetek létrehozásával (pl. Szészek) gondolták segíteni. Ma már tisztán látható ennek a megoldásnak a hatástalansága, amelynek révén az egykor dinamikusan fejlődő bányászati kisrégiókból legtöbbször talpraállásra képtelen gettósodott rozsdaövezetek alakultak ki. Hasonló sors várt a magyar uránérctermelésre, bauxitbányászatra, a rudabányai vasérctermelésre, a recsk-lahócai rézérctermelésre és a gyöngyösoroszi színesérctermelésre is. A szakképzett és vállalkozó munkaerő átcsoportosítása, esetenként exportja mellett a termelést egyre nagyobb arányban importált vendégmunkások végezték, elszakítva a bányásztelepülések és termelő üzemeik közötti korábbi szoros társadalmi kapcsolatokat. A mangánérc és az ipari ásványok termelése lelőhelyenként került kimazsolázásra, részben bezárásra, részben számos tôkeáttéten keresztül hazai vagy külföldi magánbefektetők irányítása alá. Közöttük volt több ipari ásvány előfordulásként üzemeltetett, de ércelőfordulásként is felfogható lelőhely (pl. Mád, Füzérradvány)

Eközben a földtan területén múködő állami szervezetek még több előkutatási programot tartottak múködésben, illetve indítottak (Börzsöny, Mátra, Velencei-hegység), mintegy megkésett pavlovi reflexként az előrehaladásra már képtelen és szervezetileg szétdúlt bányászati iparágakra tekintve. Ezek az előkutatási eredmények többségükben máig érdemi kiértékelés nélkül várják az adattárakban a gazdasági és technológiai felfogású értékelést. E programoknak azonban egy — a későbbiekben jelentősnek bizonyult — hozadéka az volt, hogy hozzájárult az egyetemi szférában a teleptani alapkutatások támogatásához, és alapjait rakta le azon kutatócsoportok kialakulásának az Eötvös Loránd Tudományegyetemen és a Miskolci Egyetemen, melyek a következő időszakban jelentősen hozzájárultak a hazai ércesedési rendszerek korszerú újraértékeléséhez, új teleptani modellek kidolgozásához.

1989-tôl megindult az új, piaci felfogásban kiépülő bányászati modell gazdasági és jogi megalapozása is, mely az új, XLVIII. sz. 1993. évi bányatörvény hatálybalépésével kapott gazdasági lendületet.

\section{Módszertan}

A fluidumzárvány-vizsgálatok bevezetése a hidrotermális ércesedési rendszerek kutatásába az Eötvös Loránd Tudományegyetemen és a Magyar Állami Földtani Intézetben ezen időszak elejére esik. BAKSA (1986) ércképződési tényezők alapján összehasonlította a rudabányai és a recski ércesedést, és kizárta a két ércesedés genetikai kapcsolatát. Magyarországon először készült regionális (az egész Tokaji-hegységre kiterjedő) multimédia geokémiai felvételezés finn-magyar földtani együttmúködés keretében (HARTIKAINEN et al. 1992). Néhány egykori aranybányászati terület (Telkibánya, Nagybörzsöny) középkori vágatrendszereinek újranyitása és korszerú térképezése is megindult a nyolcvanas évek végén és a kilencvenes évek elején, mintegy a következő időszak nemzetközi tőkével támogatott aranykutatásainak előhangjaként.

\section{Mecsek}

Vincze \& SOMOGYI (1984a, b) kétrészes cikkében különböző léptékben (ércesedési alapelem, érctest, ércmező) vizsgálták a mecseki felső-permben feltárt uránérclelőhely teleptani felépítését, és végigkövették annak litológiai- és redox-fácieskapcsolatait, de kitértek a tektonika szerepére is. Rámutattak a készletigazolódás és a telepmorfológia összefüggéseire, amit gyakorlati példával is megvilágítottak a különbözô kutatási (fúrási) hálósûrűségnél nyert adatok kiértékelésével. SELMECZINÉ \& ViNCZE (1986) bemutatták a Kővágószőlősi Formációban a szervesanyag-eloszlás típusait, ércesedését és nyomelemtartalmát. Vizsgálták a szénülési fokot, állást foglaltak a szerves anyag szénkőzettani-kőzetkémiai jellegét, valamint az urán nem ásványos, finom diszperz megjelenésének kötésmódját, továbbá a szénülési, ásványosodási és ércesedési folyamatsor kapcsolatát illetően. VINCZE (1987) laboratóriumi körülmények között vizsgálta az elsődleges (szingenetikus) uránfelhalmozódási és a másodlagos (epigén) uránáthalmozódási folyamatokat. Geokémiai modelljében bemutatta a szurokérc gömbös-vesés, fonalas-szalagos kollomorf kiválásainak képződését.

\section{Villányi-hegység}

VINCZE \& FAZEKAS (1991) bemutatták a Szava-1 mélyfúrással harántolt szubvulkáni riolit-porfíros mikrogránit testhez kapcsolódó elváltozási nyomokat. 


\section{Velencei-hegység}

Jelentős előkutatási munkák — geofizika, geokémia, felderítő mélyfúrások — zajlottak az 1980-as évek elsố felében a Velencei-hegységben. Ennek eredményei publikációként a Földtani Közlönyben nem jelentek meg, de a MÁFI és a MÁELGI éves jelentéseiben, egyéb kiadványaiban eredményeik követhetők (GYALOG \& HORVÁTH 2004).

\section{Bakony}

MÉSZÁROS (1983) a mangánércesedés tágabb környezetét szerkezetföldtani szempontból vizsgálva kijelölte a kutatásra perspektivikus területeket.

\section{Mátra}

A recski lelőhelyen befejeződtek az ásványinyersanyagkutatások mintegy 155 ezer méter külszínről mélyített, illetve 75 ezer méter bányabeli magfúrás elkészítésével, melyet a bányászati fejlesztési munkák, két függőakna és közöttük két főszinti vágatrendszer kihajtása előzött meg. A kutatásokat összefoglaló földtani zárójelentések anyaga nem került bele nyilvános közleményekbe. A kutatócsoport egyik utolsó összefoglalóját a mélyszintről BAKSA és munkatársai jentették meg (BAKSA et al. 1980). BAKSA (1984) ismertette az addigi recski genetikai modelleket, és bemutatta az általa kidolgozott ércképződési folyamatot.

A nyugat-mátrai kutatások (geológia, geokémia, geofizika, mélyfúrások) szintén befejeződtek, de eredményeik csak zárójelentésekben dokumentáltak, hazai tudományos folyóiratban publikálásra nem kerültek. Egyfajta zárás előtti pillanatkép rajzolódott ki BAKSA \& NAGY (1984) beszámolójából, amelyben egyúttal a recsk utóélete is említésre került. CSONGRÁDI (1984) ismertette a Gyöngyössolymos határában megismert badeni korú Asztagkő-Üstökfó higanyanomáliát, valamint meghatározta és értelmezte az ércesedés genetikáját is.

\section{Tokaji-hegység}

A Központi Földtani Hivatal megkezdte a történelmi információk alapján ismert ércelőfordulások adatainak felújítását, újragyűjtését. A HoRvÁTH \& ZELENKA (1997) által közölt összefoglaló az 1985-1991 közötti, a külszínre, a horpamezőkre és a vágatokban történt mintavételekre összpontosító munkák eredményeit ismertette.

\section{4-tól napjainkig: sikerek és kudarcok, új irányzatok, a jövóbe mutató jelek}

1993-ban született meg a nyersanyagkutatásokat is szabályozó XLVIII. számú 1993. évi Bányatörvény. Ennek létrejöttével, valamint az ércföldtani kutatásban való állami szerepvállalás elhalásával párhuzamosan az egyetemeken folyó ércföldtani alap- és alkalmazott kutatások eredményeinek egyre szélesebb mérvú nemzetközi publikálása nyomán a gyakorlati célú érckutatások megélénkültek. Ezek eredményei viszont eddig alig kerültek nyilvánosságra a Közlönyben.

Kezdeményező szerepet vállalt a MÁFI az érckutatások előkészítésében a USGS együttmúködésében elkészült üledékes kőzetekhez kapcsolt aranyércesedések vizsgálatával, s a teljes mintázási adatsorok nyilvánosságra hozatalával (KoRPÁs et al. 1999). Az itt komoly dúsulásokként jelentkező indikációkra azonban a következő 20 év során nem indult részletes kutatás vagy vizsgálat.

A Közlönyben hosszú idő után ismét helyet kaptak a határon túli magyar területekről származó tudományos közlemények, többek között az ércföldtan területéről is. E téren az Erdélyről szóló tanulmányok vannak többségben. Bár az áttekintésünk kereteit túllépné ezek részletes elemzése, mindenképp említésre méltó a Székelyföld érctelepeinek részletes ismertetése (JAKAB et al. 2005).

A legfontosabb módszertani eredményeket a hazai hidrotermás (nemes- és színesfémek) valamint üledékes eredetû (mangán, urán) nyersanyagtelepek kialakulására vonatkozó, új szemléletú telepmodellek kidolgozása jelentette. Ezeknek a gyakorlati kutatásokra is jelentős kihatása volt, mivel a hangsúlyt a földtani környezet rendszerszemléletû megértésére helyezték. E megközelítési mód alapján a korábban „meddőnek” ítélt területek (pl. az ércesedési zónáknál sekélyebb mélységben kialakult, ércesedést nem hordozó kőzetátalakulási zónák) ércpotenciálja újraértékelhetővé vált, a „,hagyományos” felderítő kutatási módszerek szükségszerúen kiegészültek a szélesebb értelemben vett földtani környezet megértésére irányuló lito- és izotópgeokémiai, geokronológiai, fluidzárvány stb. vizsgálatok alkalmazásával. Erre egy példát a Tokaji-hegység területére vonatkozóan az 5. ábra ad (MoLNÁR et al. 1999).

A megindult érckutatások hozzájárultak az egyetemi kutatóhelyek további fejlődéséhez, és jelentős új eredmények születtek elsősorban a neogén vulkánossághoz kapcsolódó ércesedések rendszerszemléletú újraértékelésének területén, melyek mostanáig nem kaptak kellő szerepet a hazai nyersanyaglelőhelyek értékelésében. Sok egyéb itt nem részletezett — tényezố mellett ez is hozzájárult a recski érces lelőhely privatizációjának sikertelenségéhez, illetve Magyarország utolsó múködố ércbányájának, az úrkúti mangánbányának 2016-os bezárásához.

Magyarország 2004-es csatlakozása az Európai Unióhoz az unió akkori nyersanyag-politikája miatt időlegesen kedvezőtlen hátteret jelentett a nyersanyagkutatás számára. Mindezek ellenére sikeres, új érckészleteket feltáró, külföldi tốke által támogatott földtani kutatások folytak a Tokaji-hegység területén (Mád, Sárospatak, Füzérradvány), a recski Lahócán, Rudabányán és a Mecsekben. E lendületet az ércföldtani kutatásokra alkalmas területek máig tartó hatályú zárttá nyilvánítása törte meg 2010-ben.

Ezzel párhuzamosan az Európai Unió nyersanyagpolitikája gyökeres változáson ment át. 2008-ban megfogalmazásra került az európai ásványi nyersanyagok kutatásának és kitermelésének szükségességét hangsúlyozó új irányelv, továbbá meghatározásra kerültek az európai ipar jelenlegi és jövőbeli ellátottsága szempontjából kritikus fémek és ásványi nyersanyagok. A kritikus nyersanyagok körének felülvizsgálata azóta is kétévente megtörténik. Az előbbi tényezôk következtében a 2014-től futó „Horizon 2020” és „EIT Raw 


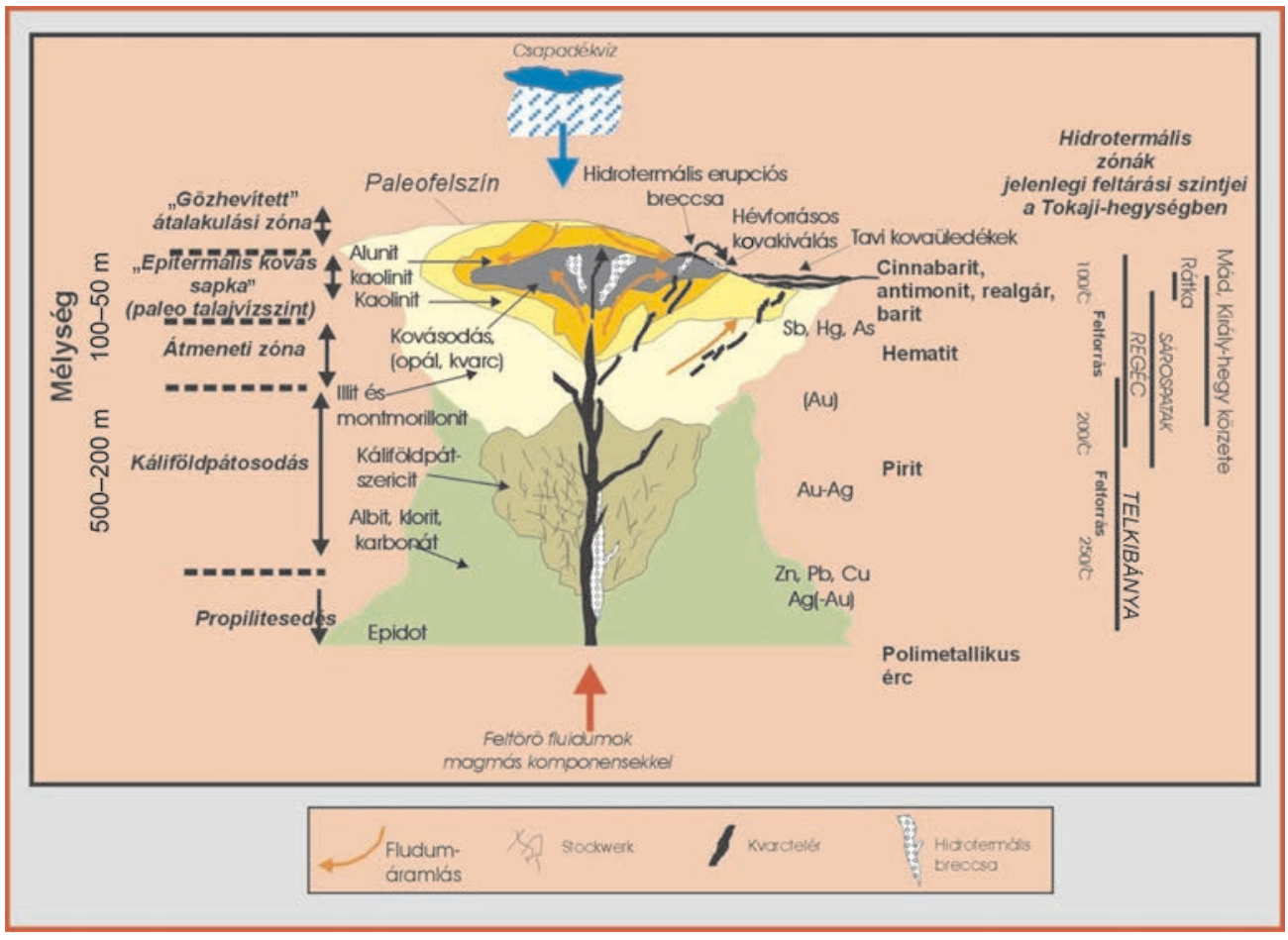

5. ábra. A Tokaji-hegység ércföldtani fejlődéstörténeti diagramja, a jobb oldalon a lelöhelyekkel, a bal oldalon az előfordulásoknak az epitermás rendszerek különböző értelmezett zónáiról származó információk összegzésével (MoLNÁR et al. 1999) Figure 5. Hydrothermal and ore geological evolution diagram of the Tokaj Mountains as summarized from the information derived from the ore occurrences shown in the right side of the diagram, showing the different levels of epithermal alteration on the left hand side of the diagram (MOLNÁR et al. 1999)

Materials" programokon belül, jelentős uniós támogatással megélénkültek mind az elsôdleges, mind a másodlagos nyersanyagokkal kapcsolatos európai kutatások. E konzorciumokban való részvétellel, sôt konzorciumok vezetésével a Miskolci Egyetem és az ELTE kutatócsoportjai szintén bekapcsolódtak az európai alap- és alkalmazott nyersanyagkutatásokba, és a programok szakhatósági és adatbáziskezelési aspektusaiban a Magyar Bányászati és Földtani Hivatal is részt vett. Ilyen pályázat keretében került sor a telkibányai ércesedés újabb kutatási eredményeit összefoglaló angol nyelvú tanulmánykötet kiadására (NÉMETH \& HARTAI 2009), illetve a recski terület továbbkutatási eredményeit összefoglaló monográfiák megjelenésére (FöLDESSY \& HARTAI, 2008). További jelentôs, a magyar nyersanyagkutatás szempontjából a jövőbe mutató tényező az, hogy a Budapesten és Miskolcon kialakult teleptani kutatócsoportok manapság már tengeren túli területeket célzó kutatásokban is részt vesznek jelentôs nemzetközi publikációs tevékenységgel és elismertséggel. Mindez a hazai szakember-utánpótlásra is visszahat - ma már jelentôs nemzetközi nyersanyagkutató vállalatok vezetô geológusi pozícióiban találunk e hazai teleptani kutatóhelyeken az utóbbi két évtizedben végzett szakembereket. Tapasztalataik remélhetôen a nem túl távoli jövőben a hazai területeken is hasznosulhatnak majd.

\section{Módszertan}

A korszerú teleptani modellek magukban foglalják az ércásványok kiválásához, illetve az ércesedést kísérô kôzet- átalakulási zónák kialakulásához vezető folyamatok geokémiai jellemzőinek ismeretét. A gyakorlati érckutatás lényegében e „geokémiai gátak” felismerésére irányul. E szempontból fontos ismereteket szolgáltatnak az ásványképződés körülményeit megvilágító laboratóriumi kísérletek. Ilyen az évtizedekkel korábban végzett hazai kísérleti eredményeket tárgyaló munka, KISS \& CORNIDES (2002) dolgozata, mely KISS János professzornak a nemzetközi mezőnyt messze megelőzve még az 1970-es években végzett évtizedes munkája esszenciájaként a karbonátos kőzetek $\mathrm{Zn}, \mathrm{Cd}, \mathrm{Mg}$, Fe, és Mn metaszomatózisát és az e folyamatok során tapasztalható szén- és oxigénizotóp frakcionációt tárgyalta.

Új mikroszkópi eljárás sikeres bevezetéséról számolt be TAKÁCS \& MolNÁR (2011) az infravörös fényben végzett fluidzárvány-vizsgálatok területéről.

Az ásványvagyon-osztályozás és a nyersanyagkészletek felmérését összefoglaló kutatási jelentések nemzetközi szabványrendszerének hazai meghonosítására már megindultak a törekvések (HoRváTH et al. 2016), de a magyarországi nyersanyag-potenciál korszerú felméréséhez a modern ércföldtani szemlélet alkalmazása nem mellőzhető.

Az utóbbi néhány évtizedben megélénkült archeometriai kutatások egy jelentős része szintén nem nélkülözheti az ércföldtani és ércásványtani ismereteket. Az ércföldtani megközelítés archeometriai alkalmazására egy szép példa a somogyi gyepvasércekról szóló munkájában található (KERCSMÁR \& THIELE 2015). 


\section{Soproni-hegység}

Újabb részletes információk jelentek meg a korábban a MÉV által lebonyolított kutatásról a fertôrákosi metamorf palaösszletben jelentkezô színesfémérc $(\mathrm{Cu}, \mathrm{Zn}, \mathrm{Pb})$ és urán-ritkaföldfém dúsulások anyagvizsgálatairól (VINCZE et al. 1996). Az ércesedést retrográd metamorf diaftorézis során fellépő hidrotermális metaszomatikus folyamatoknak tulajdonították.

\section{Velencei-hegység}

A terület új módszerekkel történó kutatása az ELTE ércföldtani kutatócsoportja által ebben az időszakban kezdődött, és ekkor a kutatások homlokterében a paleozoos gránitban megjelenő, korábban mind a variszkuszi, mind a paleogén magmatizmushoz kapcsolt hidrotermális ércesedések és átalakulási zónák elkülönítése szerepelt. Az új eredmények közül a Retezi-lejtakna részben a gránitban, részben az azt befogadó paleozoos agyagpalában előforduló molibdenites ércesedésre vonatkozó ásványtani és fluidzárvány-vizsgálatok eredményeit a Közlöny hasábjain MoLNÁR (1997) publikálta. Az eredmények bizonyították, hogy a molibdenites ércesedést a variszkuszi gránithoz kötődő hidrotermális folyamatok hozták létre. A paleozoos gránitot érintô, de a kainozoos vulkanizmushoz kapcsolható hidrotermális folyamatok szerkezetföldtani jellemzőit és kiterjedését értékelte a fluidzárványsíkok szisztematikus vizsgálata alapján BENKó et al. (2008). A fluidzárvány és KAr radiometrikus kormeghatározási vizsgálatok ötvözése révén BENKó et al. (2012) kimutatta a Meleg-hegy gránitjában húzódó baritos érctelérek kapcsolatát a paleogén vulkanizmushoz társuló hidrotermás folyamatokkal.

\section{Mecsek}

Az uránérckutatások „,melléktermékeként” kapott információk feldolgozása a mecseki lelőhely környezetében is megindult. Ennek egyik eredményét közölte Csicsák \& SZAKMÁNY (1998) a Jakabhegyi Homokkő legfelsô, ún. átmeneti rétegeinek részletes elemzésével. Ez a világszerte rézpala néven ismert érctípus hazai megjelenésének földtani környezetét mutatta be, jelezve a $\mathrm{Cu}, \mathrm{As}, \mathrm{Zn}, \mathrm{Ag}$ elemek erôteljes dúsulását a legfelső szürke homokkốben. Részben külföldi tôke bevonásával az uránérc oldásos technológiával történő kinyerésére indultak földtani kutatások a kétezres évforduló időszakában. E munkálatok során a Dinnyeberki közelében előforduló uránércesedés teleptani jellemzőit vizsgálták (KonRÁD et al. 2012). E munka lényeges felismerése az volt, hogy a ércesedés a permi uránfelhalmozódások kainozoos remobilizációjával jött létre. VINCZE et al. (2011) szintén az urán remobilizációjához kapcsolta a mecseki gránitban talált teléres-eres uránérc-indikációk kialakulását. Az ELTE ércföldtani kutatócsoportja a Velencei-hegység gránitintrúzióján sikerrel alkalmazott, hasonló szemléletú és módszertanú vizsgálatok körét a mecseki granitoidok területére is kiterjesztette. A gránitot ért hidrotermás felülbélyegzéseket és azok szerkezetföldtani hátterét, a repedésrendszerek fejlődéstörténetének körvonalazását SZABÓ et al. (2008) és PoROS et al. (2008) dolgozatai közölték.

\section{Bakony}

Ebben az idôszakban is tovább folytatódott a mangánércesedés tudományos kutatása: egyrészt az úrkúti archív minták (PolgÁRI et al. 2003a), másrészt eplényi mangánérc bányából származó minták modern szemléletú, nagymúszeres vizsgálatával (PoLGári et al. 2003b). A mangánércbányászat kutatása alatt lemélyített fúrások egységes, geológiai újrafeldolgozását és értékelését BIRó (2014) végezte el. Biró \& PÁL-Molnár (2015) a bakonyi primer oxidos mangánércek (Úrkút: Csárda-hegy, Eplény) komplex, genetikai szempontú nyomelem- és ritkaföldfém-vizsgálatát végezték el.

\section{Budai-hegység}

Molnár \& GatTer (1994) a Budai-hegységben és egyéb magyarországi lelőhelyeken előforduló baritkristályok morfológiai és fluidzárvány-vizsgálataival adott új eszközt e fontos és gyakori hidrotermális kísérő ásvány hazai előfordulásainak összehasonlító vizsgálatához, arra a következtetésre jutva, hogy az üledékes környezetben megjelenő barit eredete is hidrotermális folyamatokhoz köthető. Gál et al. (2008) a Hárshegyi Homokkő kovásodását és baritteléreinek kialakulását vizsgálták. Az eredmények arra utalnak, hogy a kovás átalakulási zónák a paleogén vulkanizmushoz köthetőek, míg a barittelérek a miocén vulkánosság által indukált hidrotermális folyamatokhoz kapcsolhatók.

\section{Börzsöny}

Megindult, majd leállt a börzsönyi nemesfém-ércesedések kutatása. A munkákról a későbbiekben NAGY (2002) számolt be.

\section{Mátra}

Gyöngyösoroszi és Mátraszentimre területén részben bányabezárási munkák folytak, viszont erre az idôszakra esik a recski Lahóca aranyércesedésének megkutatása és a kutatások ásványvagyonbecsléssel történő lezárása. Az 1980-as években megismert porfíros és szkarnos rézércesedés fölötti zónában, a korábban kimerültnek vélt lahócai $\mathrm{Cu}-\mathrm{Au}$ bánya szélesebb környezetében $0,5 \mathrm{~g} / \mathrm{t}$ Au határérték mellett 37,5 millió tonna $1,45 \mathrm{~g} / \mathrm{t} \mathrm{Az}$ és $0,12 \% \mathrm{Cu}$ átlagminőségú, magas szulfidizációs fokú epitermális aranyércesedést mutatott ki egy ausztrál-magyar kutatócsoport (FöLDESSY 1997). Több kiegészítô vizsgálati eredmény is született, pl. Ni-telluridok jelenlétéról a lahócai ércekben (GELLÉRT et al. 1998). Az ipari nyersanyag-kutatási munkák az akkor kirobbant világméretú, aranyelőfordulásokkal kapcsolatos kanadai-indonéz tôzsdei csalás (BRE-X csalás) mellékhatásaként szakadtak félbe. További hasznosítására, gazdasági értékelésére azóta nem került sor, de a tudományos kutatások tovább folytatódtak a recski porfíros/ szkarn-epitermális ércesedési rendszer felszínközeli zónáiban. Részben az OTKA, részben iparvállalatok támogatásával végzett egyetemi kutatások, illetve korábbi kutatási programok még nem publikált eredményeit foglalta össze a lelőhely angol nyelvú tanulmánykötete (FöLDESSY \& 
HARTAI 2008). Ebben a kötetben kapott helyet MoLNÁR et al. (2008) tanulmánya, amelyben a porfíros rézércesedéshez csatlakozó epitermás átalakulási zonációt ismertetik. A lelőhelyről számos nemzetközi publikáció is napvilágot látott az utóbbi években, melyek közül TAKÁcs et al. (2017) dolgozata a legjelentősebb.

\section{Bükk hegység}

Az 1960-as évektôl kezdődően az 1980-as évekig folyt uránkutatások értékelése korábban csak kéziratos és nem hozzáférhetố jelentésekben szerepelt. A gyengén metamorfizált-deformált permi Szentléleki Formáció homokkövében a kovásodott, karbonátosodott, cerrusszitosodott és albitosodott alapanyagban U-Ti-oxidok, kasolit és uranofán feldúsulásához köthető ércindikációk fordulnak elő (SzABó \& ViNCZE 2002). Érdekesség, hogy az alpi hegységképződési folyamat fluidum-mobilizációs eseményeihez (127 és 75 millió év) köthetô epigenetikus-metaszomatikus uránércesedés fedőszárnyán egy polimetallikus-szulfidos $\mathrm{Pb}-\mathrm{Zn}$ ércesedés előfordulását is felderítették. A ladin-karni kvarcporfír tufa összletben U-Be-ritkaföldfém dúsulásait mutatták ki (SzABó \& VINCZE 2013). Az Európai Unióban a „kritikus fémek és ásványok” jelentőségének megnövekedése a Bükk triász korú vulkanitjaiban előforduló ritkaföldfém-koncentrációk újravizsgálatát eredményezte. A vizsgálatok szerint a ritkaföldfémeken kívül a $\mathrm{Zr}, \mathrm{Nb}$ és Th dúsulásai a monazit-Ce, továbbá Nb-tartalmú Ti-oxidok előfordulásához köthetők. Az ércindikáció zónáit a kőzet kálimetaszomatikus átalakulása kíséri (NÉMETH et al. 2016).

\section{Aggtelek-Rudabányai-hegység}

A rudabányai ércbánya termelésének leállítása egyúttal a kutatások félbeszakadásával járt. Megindult az archivált, de nem közölt anyagok feldolgozása. Ennek egyik jó példája a SZENTPÉTERY (1997) által ismertetett Rb-690 szerkezetkutató fúrás értékelése, jelezve a rudabányai vasérc-előfordulás szerkezeti lehatároltságának bizonyítékait. 2006tól színesfémérc- és baritkutatások folynak a Rudabánya vasérclelőhely környezetében. A kutatások alapjaiban változtatták meg a lelőhelyet létrehozó folyamatok képét, valószínúsítve a különféle ércesedések egymásra települését több szakaszban, az alsó-triásztól kezdve a pliocénig. Az üledékes exhalációs ércesedéstől az epigenetikus szerkezetekhez kapcsolódó $\mathrm{Pb}-\mathrm{Zn}-\mathrm{Ba}$ érctípusokon keresztül az oxidációs övben létrejött másodlagos dúsulásokig terjednek a genetikai változatok. Egy köztes értékelési állapot helyzetképe rajzolódik ki a FöLDESSY et al. (2010) által közreadott tanulmányban. Egy ebben közölt, az árkolásokban feltárt jelentős cinkércdúsulásokról készült térkép látható a rudabányai Andrássy-1 bányarész területérôl a 6. ábrán.

\section{Tokaji-hegység}

Az egyik legígéretesebb aranyércesedési régiónk kutatását alapozták meg a Magyar Állami Földtani Intézet és a Finn Geológiai Szolgálat együttmúködésében elkészült, korszerú áttekintő geokémiai és légi-geofizikai felmérések eredményei, melyeket HoRvÁTH et al. (1993) foglalt össze.

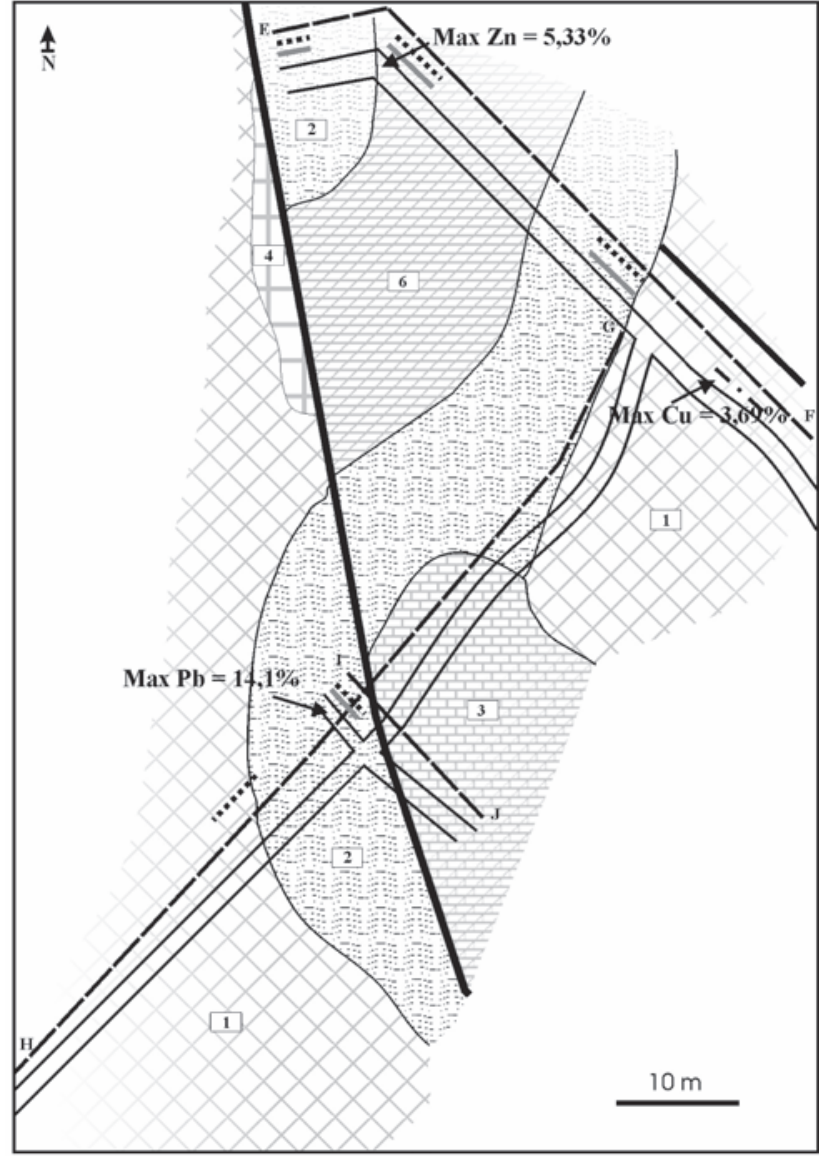

6. ábra. Epigenetikus $\mathrm{Pb}-\mathrm{Zn}-\mathrm{Cu}$ dúsulások törészóna mentén. A4 kutatóárok, Rudabánya (FöLDESSY et al. 2010)

Jelmagyarázat: (1) Limonit barnavasérc, (2) Agyagmárga (Szini M Formáció), (3) Sziderites pátvasérc, (4) barit, (5) Hidrotermális breccsa (6) Breccsásodott dolomit (Guttenstein Dolomit F). Az elemzési értékek az árokban vett 2-4 m hosszú résmintákra vonatkoznak

Figure 6. Fault controlled epigenetic $\mathrm{Pb}-\mathrm{Zn}$-Cu enrichment, A4 trench, Rudabánya (FöLDESSY et al. 2010)

Legend: (1) Limonite, (2) Marl (Szin Marl F), (3) Siderite, (4) Baryte, (5) Hydrothermal breccia, (6) Brecciated dolomite (Guttenstein Dolomite F). The assay values refer to $2-4 \mathrm{~m}$ long channel samples along the trench

A rendszerváltozást követôen a Tokaji-hegység volt az első olyan terület, ahol koncessziós pályázatok kiírására került sor (Telkibánya és Füzérradvány), és ahol külföldi nyersanyagkutató vállalatok (RTZ, Humex, Kazminco) munkálatokat kezdtek az egykori nemesfém-bányászati területek újraértékelése terén. Ezeknek az eredményeknek a publikálása magyarul nem történt meg, de egyes eredményeket a fentiekben már hivatkozott MoLNÁr et al. (1999) munkája magában foglalt. A külföldi tôkével folyó nyersanyagkutatási programok mellett, azokkal részben együttmúködve, az ELTE ércföldtani kutatócsoprtja is aktívan hozzájárult a terület ércgenetikájának korszerú értékeléséhez. E munkák közül MoLNÁR (1994) a hegység keleti peremén található rudabányácskai előfordulás környezetének ércgenetikai képét ismertette, jelezve az epitermás keletkezési folyamatot és a feltételezhetően 220-300 m keletkezési mélységet. CsONGRÁDI et al. (1996) a füzérradványi Korom-hegyen a kilencvenes években folytatott érckutatás eredményeit foglalta össze. A későbbi fúrásos 
kutatások az egykor múködő illitbánya képződményeiben megjelent $\mathrm{Au}-\mathrm{Ag}$-ércesedéshez további ismereteket szolgáltattak, melyeket CSONGRÁDI et al. (2014) tanulmánya foglalt össze. $\mathrm{Az}$ ipari szempontból jelentős Au-Ag-potenciállal rendelkező lelőhely kutatása napjainkig befejezetlen.

\section{Sárbogárd}

A község közelében (Sárszentmiklóson) felszínre bukkanó miocén ,alsó riolittufa szint" hidrotermás kőzetátalakulási jellemzőinek újravizsgálata során (SzENTPÉTERI \& MOLNÁR 2000) a korszerú teleptani modellezés módszereit alkalmazva megállapították, hogy az előfordulás jellemzői az észak-magyarországi neogén mészalkáli intermediersavanyú vulkanizmushoz kapcsolodó adulár-szericit típusú (alacsony szulfidizációs fokú epitermás) aranyércesedésekkel összevethetôek. Ezek alapján tehát ez a megkutatatlan terület is rendelkezik nemesfém-kutatási potenciállal.

\section{Következtetések és jövókép}

A Közlöny történetéből 172 közleményt emeltünk ki, amelyet a hazai ércföldtannal kapcsolatosnak tekintettünk. Ezt további 17 hivatkozással egészítettük ki, hogy az áttekintésünk és az egyes időszakokban lezajlott szakmai történések egyensúlyát megteremtsük. A Közlönyben napvilágot látott ércföldtani közlemények száma mintegy 5-6\%-át teheti ki a teljes cikkanyagnak. Ennek kevesebb, mint $10 \%$-a foglalkozik több területet is érintő vizsgálatokkal vagy módszerfejlesztési eredményekkel. A regionális vizsgálatokkal foglalkozó közleményeket korszakokra és az áttekintésünkben szereplő területekre szétbontva a leggyakrabban előforduló tanulmányok az 1920 előtti időszakban a Felvidékhez és Erdélyhez, az azt követő időszakokban a Mecsekhez (16\%) és a Mátrához (22\%) kötődnek. Ha figyelembe vesszük, hogy még ezeken a területeken is bőséges a fel nem dolgozott vagy meg nem kutatott ércföldtani információ, fokozottan igaz ez a továbbiakra, jelezve a jövőnek, hogy még számos kiaknázatlan lehetőséget rejt a hazai földtani környezet.

Az egyes időszakok közül az 1960-1979 közötti évek jelentik a csúcsot, a cikkek egyharmadát ebben az időben publikálták. A mélypontokat mindig a nagy politikai, gazdasági változásokat követô idők jelentik, amelyek később új fellendülést alapoztak meg (I. táblázat).

A másfél évszázados történetet hullámhegyek és -völ- gyek egyaránt jellemzik, ezeket a társadalom, a határok, az iparszerkezet és politikai irányítás sokszor 180 fokos változásai kísérték, illetve idézték elő. Az ország mindenkori szakemberállománya - a Közlöny publikációiban is láthatóan — komoly erôfeszítéseket téve válaszolt ezekre a kihívásokra az aktuális törvényi és pénzügyi korlátok között. Az utolsó két évtized a csökkenő állami figyelem időszaka, amelynek során az ásványinyersanyag-gazdálkodás eltávolodott a hazai és a korszerú, környezetkímélô technológiák új nyersanyagbázisát jelentő érckutatási és bányászati lehetőségektől, miközben a feldolgozóipar fejlesztésére és mezőgazdaságunk erősítésére jelentős többlet erôforrásokat összpontosítottak. Ez hosszú távon egyensúlyhiányt okozhat.

Ugyanakkor a hazai egyetemi szférában kialakultak és megerősödtek olyan kutatócsoportok, melyek a nemzetközi elméleti és gyakorlati kutatások fô irányaihoz kapcsolódva továbbra is képviselik az ércföldtani ismeretek és kutatások bázisát. A Földtani Közlöny 150 évének ércföldtani jellegû́ publikációit áttekintve látható, hogy az ásványi nyersanyagainkkal kapcsolatos információk felújítására, globális, illetve kontinentális keretekben való újraértelmezésére és ezt követően az adatbázisok rendszeres karbantartására a továbbiakban is szükség van.

A hazai földtani környezet még számos meg nem kutatott, sốt fel sem ismert, gazdaságilag is jelentős és szükséges ásványinyersanyag-forrást rejthet, amelyeknek megismerésére közös társadalmi érdekünk mentén törekednünk kell.

\section{Köszönetnyilvánítás}

Kéziratunk bírálói, CSONGRÁDI Jenő és MARTON István részletes és hasznos észrevételeikkel nagyban hozzájárultak a végleges változat jobb minőségéhez, pontosságához, információtartalmához. 


\section{Irodalom — References}

BAKSA Cs. 1975a: Új enargitos-luzonitos-pirites ércesedés a recski Lahóca-hegy É-i előterében. — Földtani Közlöny 105, 58-74.

BAKSA Cs.1975b: A recski mélyszinti szubvulkáni andezittest és telérei. - Földtani Közlöny 105, 612-624.

BAKSA Cs. 1984: A recski ércesedés genetikai vizsgálata. — Földtani Közlöny 114, 335-348.

BAKSA Cs. 1986: A recski és a rudabányai ércesedések eredetének összehasonlító elemzése. — Földtani Közlöny 116, 353 -361.

Baksa, Cs., Cseh Németh, J., Csillag, J., Földessy, J. \& ZelenKa, T. 1980: The Recsk porphyry and skarn copper ore deposit, Hungary. — In: Jankovic, S. \& Sillitoe, R. (eds): European Copper Deposits. Beograd, 73-76.

BAKSA Cs. \& NAGY G. 1984: Érckutatási helyzetkép a Mátra-hegységről. - Földtani Kutatás 27, 17-19.

BALLA Z. 1967: Az uránércesedés és a kőzetek színe közötti összefüggés vizsgálata. — Földtani Közlöny 97, 127-143.

BALLA Z. 1969: A szerkezeti tényezők szerepe az uránércesedésben. - Földtani Közlöny 99, 235-244.

BALLA Z. 1973: A diagenezis második szakaszának uránércképző szerepérôl. —Földtani Közlöny 103, 166-174.

BALLA Z. \& DudKo A. 1972: A nyugat-mecseki urán elsődleges felhalmozódásáról. — Földtani Közlöny 102, 324-333.

BALLA Z. \& DudKo A. 1973: Az uránáthalmozódás ércképződésben játszott szerepéról. — Földtani Közlöny 103, 49-57.

BALOGH K. \& PANTó G. 1953: A Rudabányai-hegység földtana. — A Magyar Állami Földtani Intézet Évi Jelentése 1949-rôl, 135-154.

BÁNYAI J. 1919a: Az aranyosbányai kontakt területről. — Földtani Közlöny 49, 9-15.

BÁNYAI J. 1919b: Aranytartalmú érces telérek mikroszkópos vizsgálata. — Földtani Közlöny 49, 15-21.

BARABÁs A. 1979: A perm időszak földtani viszonyai és a külszíni kutatás feladatai a mecseki érclelőhelyen. — Földtani Közlöny 109, 357-365.

BARABÁs A. 1997: A hazai uránkutatás, uránbányászat és a geológia. — Földtani Kutatás 34, 4-11.

BARABÁSNÉ STUHL Á. 1973: A nyugat-mecseki felsőperm összlet üledékföldtani jellegei statisztikus értékelésének rétegtani és egyéb földtani eredményei. - Földtani Közlöny 103, 381-388.

BARANyi I., Berta Z., SzAbó J., VAdos I. \& VÁRhegYi A. 1997: A geofizika szerepe a hazai uránbányászatban. — Földtani Kutatás 34, $20-24$.

Benkó Zs., Molnár F. \& LesPinasse, M. 2008: Fluidzárványsíkok és repedésrendszerek vizsgálatának alkalmazása granitoid kőzetek repedezettségének fejlődéstörténeti rekonstrukciójában I.: Módszertani alapvetés és alkalmazás a Velencei-hegység fluidummobilizációs folyamataira. — Földtani Közlöny 138, 229-246.

Benkó Zs., Molnár F., PéCskay Z., NéMeth T. \& Lespinasse, M. 2012: A paleogén vulkanizmus hidrotermális rendszerének hatása a variszkuszi gránitra a Velencei-hegységben: a sukorói barittelér kora és képződése. - Földtani Közlöny 142, 45-58.

BIRÓ L. 2014: Az úrkúti mangánérc-bányászat fúrásainak sztratigráfiai újraértékelése. — Földtani Közlöny 144, 3-14.

BiRó L. \& PÁL-MolnÁr E. 2015: A bakonyi primer oxidos mangánércek nyomelem- és ritkaföldfém-geokémiai vizsgálata. —Földtani Közlöny 145, 119-126.

BoDrogi F. 1979: Gazdasági és geológiai paraméterek összefüggései a mecseki ércbányászatban. — Földtani Közlöny 109, 401-408.

BöcKH H. 1901: Előzetes jelentés a Selmeczbánya vidékén előforduló eruptív kőzetek korviszonyairól. — Földtani Közlöny 31, 289 -328.

CORNIDES I., KISS J. \& SZEREDAI L. 1966: A középső-mátrai érctelér képződési hőmérséklete az ${ }^{18}$ O-izotóp relatív gyakorisága alapján. — Földtani Közlöny 96, 43-50.

CSEH L. 1886: A vihnyei Ó-Antaltárna bányatelep földtani viszonyai. — Földtani Közlöny 16, 224-227.

CSEH L. 1890: A selmeczi Ferencz-császár-altárna geológiai szelvénye. — Földtani Közlöny 20, 23-26.

CseH NÉMETH J. 1958: Az úrkúti mangánérctelep kifejlődési típusa I. — Földtani Közlöny 88, 399-415.

CSEH NÉMETH J. 1967: Úrkút és Eplény mangánterületeinek összehasonlítása. — Földtani Közlöny 97, 29-38.

CSEH NÉMETH J. 1975: A recski mélyszinti színesfémérc előfordulás és annak teleptani ércföldtani képe. — Földtani Közlöny 105, 692 708.

CSEH NÉMETH J. 1979: Az érc- és ásványbányászati iparág bányaföldtani megfigyelési, dokumentálási rendszere, legfontosabb kutatási programok. - Földtani Közlöny 109, 449-458.

CsICSÁK J. \& SZAKMÁNY G. 1998: A Jakabhegyi Homokkő Formáció legfelső, ,„átmeneti” rétegei kôzettani-geokémiai vizsgálatának eredményei. - Földtani Közlöny 128, 535-553.

CSILLAG J. 1975: A recski terület magmás hatásra átalakult képződményei. — Földtani Közlöny 105, 646-671.

CsONGRÁDI J. 1975: A recski mélyszinti színesfémércesedés jellemzése ércmikroszkópi vizsgálatok alapján. — Földtani Közlöny 105, 672-691.

CSONGRÁDI J. 1984: Hidrotermális kőzetelváltozások és színesfém-eloszlás a gyöngyössolymosi üstökfői higanyindikációs zónában. — Földtani Közlöny 114, 113-121.

Csongrádi J., Tungli G. \& ZelenKa T. 1996: Az utóvulkáni múködés és az ércesedés kapcsolata a füzérradványi KoromhegyKoromtetőn. - Földtani Közlöny 126, 67-75.

CSONGRÁdI J., ILKEYNÉ PERLAKI E. \& ZELENKA T. 2014: Újabb adatok a füzérradványi hévforrásos epitermális arany-ezüst ércesedésről. —Földtani Közlöny 144, 383-390.

CZECK V. 1912: A radioaktivitás és szerepe az újabbkori földrajz-geológiai felfogásokban. — Földtani Közlöny 42, 428-455.

DANK V. 1975: A recski mélyszinti érckutatások tudományos és gazdasági jelentősége. — Földtani Közlöny 105, 559-564.

ERDÉLYI J., TolnAY V. \& Koblencz V. 1957: A nagybörzsönyi agyagásvány és az ércesedés néhány újabb kíséróásványa. — Földtani Közlöny 87, 400-418.

F. JÁRÁNYI K. 1975: A recski mélyszinti alaphegységi üledékes képződmények. — Földtani Közlöny 105, 598-611.

FAZEKAS V., SELMECZI B. \& KóSA L. 1975: Ritkaföldfém ásványosodás a Soproni-hegység kristályos paláiban. — Földtani Közlöny 105, 297-308. 
FöLDESSY J. 1975: A recski rétegvulkáni andezitösszlet. — Földtani Közlöny 105, 625-645.

FöLDESSY J. 1997: A recski Lahóca aranyérc előfordulás. - Földtani Kutatás 34, 12-15.

FÖLDESSY J. \& BAKSA Cs. 1979: A recski enargitos rézérctermelés tapasztalatainak és a mélyfúrásos kutatás adatainak elemző értékelése. - Földtani Közlöny 109, 478-487.

FöldESSY, J. \& HARTAI, É. (eds) 2008: Recsk and Lahóca geology of the paleogene ore complex. - Publications of the University of Miskolc Series A, Mining 73, 86 p.

Földessy J., NÉMETh N. \& Gerges A. 2010: A rudabányai színesfém-ércesedés újrakutatásának előzetes földtani eredményei. — Földtani Kutatás 140, 281-292.

FöLDVÁRI A. 1947a: A molibdén velencei-hegységi előfordulásának teleptani viszonyai. — Postvolcanic Molibdenium-Traces in the Velence Mountain. - A Magyar Állami Földtani Intézet Évi Jelentése, B) Beszámoló a vitaülésekról 1947/3, 9, $39-57$.

FöLDVÁRI A. 1947b: Érckutató fúrás Velence községben. — Jövedéki Mélykutatás 1947/48. évi munkálatairól, 111-116.

FRANZENAU Á. 1892: A Brád környékén tett nagy termés arany leletről. — Földtani Közlöny 22, 80-82.

FÜLÖP J. 1975: Új perspektívák a hazai földtani kutatás előtt. — Földtani Közlöny 105, 565-570.

GAGYi PÁlFFY ID. A. 1975: A recski mélyszinti ércesedés megismerése, általános jellemzése és népgazdasági jelentősége. — Földtani Közlöny 105, 571-581.

GAGYI PÁLFFY IFJ. A. 1975: A recski mélyszinti színesfémérc előfordulás gazdasági-múrevalósági értékelése és felismert törvényszerúségei. - Földtani Közlöny 105, 709-723.

Gál B., Poros Zs. \& Molnár F. 2008: A Hárshegyi Homokkő Formáció hidrotermális kifejlődései és azok kapcsolatai regionális földtani eseményekhez. — Földtani Közlöny 138, 49-60.

Gellért B., Buzogány P. \& Weiszburg T. 1998: Melonit $\left(\mathrm{NiTe}_{2}\right)$ a recski Lahóca Cu-Sb-As-Au epitermás ércesedéséből. — Földtani Közlöny 128, 585-606.

GeSELL S. 1884: 8. Jelentés a Selmeczbányán és környékén 1882. és 1883-ban eszközölt részletes bányageológiai felvételekről. — Földtani Közlöny 14, 273-283.

Gesell S. 1885: II. Fölvételi jelentések - 8. A Selmeczbánya és Szélakna környékén 1884-ben eszközölt részletes bányageologiai fölvételekről. - Földtani Közlöny 15, 335-349.

GöBEL E. 1956: A rudabányácskai Nagybányi-hegy környékének bányaföldtani leírása. — A Magyar Állami Földtani Intézet Évi Jelentése az 1954. évról, 45-62.

GYALOG L. \& HoRvÁTH I. (szerk.) 2004: A Velencei-hegység és a Balatonfő földtana: Magyarazó a Velencei-hegység földtani térképéhez (1:25 000) és a Balatonfó-Velencei-hegység mélyföldtani térképéhez (1:100 000). — Magyar Állami Földtani Intézet, Budapest, 316 p.

Hartikainen, A., Horváth, I., ÓdoR, L., Ó. Kovács, L. \& CsOngrádi, J. 1992: Regional multimedia geochemical exploration for Au in the Tokaj mountains, northeast Hungary. — Applied Geochemistry 7/6, 533-545., https://doi.org/10.1016/0883-2927(92)90069-F

Hermann M. 1952: Telkibányái riolitok és andezitek petrográfiája és petrokémiája. - Földtani Közlöny 81, 345-367.

HERNYÁK G. 1977: A Rudabányai-hegység szerkezeti elemzése az elmúlt 20 év kutatásai alapján. — Földtani Közlöny 107, 368-374.

HoRvÁTH I., Ódor L., FÜGEDI U. \& AIMO H. 1993: Aranyindikációk a Tokaj-hegységi geokémiai érckutatásban. — Földtani Közlöny 123, 363-378.

HoRvÁTH J. \& ZelENKA T. 1997: A telkibányai nemesfém-ércesedés legújabb bányaföldtani adatai és értékelése. — Földtani Közlöny 127, 405-430.

HoRvÁTH Z., SÁRI K. \& FodOR B. 2016: A nemzetközi ásványvagyon-osztályozási keretrendszer és a szilárd ásványi nyersanyagok kutatási jelentéseire vonatkozó szabványok. — Földtani Közlöny 146, 107-120.

ILKEYNÉ PERLAKI E. 1961: Vulkáni hipo- és meta-elváltozások andezit-riolittufa érintkezésen tokaji-hegységi példákon. — Földtani Közlöny 91, 382-390.

INKEY B. 1879: A boiczai ércztelérek mellékkőzetéről. — Földtani Közlöny 9, 365-375.

JaKab Gy., LACZKó A-A., ZÓlya É. G., Zólya L. A., PÁl-Molnár E., ZaKAriás L. 2005: A Székelyföld érctelepei. — Földtani Közlöny 135, 459-478.

JANTSKY B. 1953: A demjéni limonitos mangánérc települési viszonyai. — A Magyar Állami Földtani Intézet Évi Jelentése az 1950. évról, 61-63.

JANTSKY B. 1957: A Velencei hegység földtana. — Geologica Hungarica series Geologica 10, 166 p.

KASZANITZKY F. 1959a: A pátkai kőrakáshegyi érckutatás jelenlegi állása. — Földtani Közlöny 89, 133-142.

KASZANITZKY, F. 1959b: Genetic relations of ore occurrence in the Western Mátra Mountains, North Eastern Hungary. — Annales historico-naturales Musei Nationalis Hungarici 51, 5-28.

KerCsmÁr Zs. \& THIELE Á. 2015: A belső-somogyi gyepvasércek genetikája, geokémiai jellemzői és archeometallurgiai jelentősége. — Földtani Közlöny 145, 53-72.

KISS J. 1951: A szabadbattyáni Szárhegy ércgenetikai alkata. — Földtani Közlöny 81, 264-274.

KIss J. 1958: Ércföldtani vizsgálatok a siroki Darnó-hegyen. — Földtani Közlöny 88, 27-41.

KIss J. 1960: Az urán-króm-vanádium eloszlása és az epigén krómcsillám szerepe a mecseki permi összletben. — Földtani Közlöny 90 , $73-82$.

Kiss J. 1963: Az uránmigráció hidrotermális feltételei és a szurokércgenezis. — Földtani Közlöny 93, 74-81.

KISS J. 1964: Allitos és sziallitos ásványok és szerepük a Középső-Mátra ércesedésében. — Földtani Közlöny 94, 422-431.

KISS J. 1982: Ércteleptan I-II. — Tankonyvkiadó, Budapest.

KISS J., CORNIDES I. \& SzEREDAI L. 1966: A középső-mátrai érctelér képződési hőmérséklete az ${ }^{18}$ O-izotóp relatív gyakorisága alapján. — Földtani Közlöny 96, 43-50.

Kiss J. \& CoRnides I. 2002: Kalcit (mészkô) Zn, Cd, Mg, Fe, és Mn metaszomatózisa és az O-C izotóp összetételének változása hidrotermális körülmények között. — Földtani Közlöny 132, 95-116. 
KISS J. \& VIRÁGH K. 1959: Urántartalmú foszfátos kôzet a balatonfelvidéki (Pécsely) triász-összletben. — Földtani Közlöny 89, 85-97. Kосн A. 1880: A Czibles és Oláhláposbánya vidéke zöldkőandesitjeinek új petrographiai vizsgálata. — Földtani Közlöny 10, 138-146.

Kосн S. 1953: A Mád és Regéc környékén fekvő vasércelőfordulások genetikája. — A Magyar Állami Földtani Intézet Évi Jelentése az 1950. évról, 84-88.

Koch, S. \& GrasselLy, G., 1952: The minerals of the sulphide ore-deposite of Nagybörzsöny. — Acta Universitatis Szegedensis 6, 23-30.

KonRÁD GY., FöLDING G., BARABÁs A. \& UNYI P. 2012: A dinnyeberki uránércesedés földtana, kísérleti perkolációja és rekultivációja. Földtani Közlöny 142, 357-374.

Korpás, L., Hofstra, A. H., Ódor, L., Horváth, I., HAAs, J. \& LoeventHAL, J. S., 1999: The carlin gold project in Hungary (1995-1998). - Geologica Hungarica series Geologica 24, 151-167.

KovÁcs Z. 1970: Ritkaföldfémek koncentrálódása az oxidos mangánérc átmeneti övezetében. — Földtani Közlöny 100, 91-95.

KREMNITZKY J. F. 1888: Az érczképződésre vonatkozó megfigyelések a verespataki érczhegység övében. — Földtani Közlöny 18, 479-482. KuBINYI F. 1867: A recski termésréz képletról és a dioritról amelyben találtatik. — A Magyarhoni Földtani Társulat munkálatai, Pest, 1-7.

Kubovics I. 1956: A Velencei-hegység talajának nyomelem vizsgálata. — Földtani Közlöny 86, 217-243.

KuBovics I. 1958: A sukorói Meleghegy hidrotermás ércesedése. - Földtani Közlöny 88, 299-314.

KuBovics I. 1960: A velencei-hegységi utómagmás képződmények nyomelem vizsgálata I. Szkandium-nióbium és kísérő nyomelemei. —Földtani Közlöny 90, 273-292.

KuBovics I. 1966: A kálimetaszomatózis szerepe a nyugat-mátrai kőzetképződésben. — Földtani Közlöny 96, 13-26.

Kun B. (szerk.) 1989: 25 éves az Országos Érc-és Ásványbányák. — OÉÁ, Budapest.

LACKNER A. 1904: A kazanesdi kén-kovandbánya Hunyad vármegyében. —Földtani Közlöny 34, 399-415.

LACKNER A. 1906: Újabb adatok a kazanesdi kénkovandbánya környékének geológiai viszonyaihoz. — Földtani Közlöny 36, 283 -289.

LENGYEL E. 1948: Telkibánya környékének ércgenetikai viszonyai. — Jelentés a Jövedéki Mélykutatás 1947/48. évi munkálatairól, 308-319.

LENGYEL E. 1957: A börzsönyi vasas képződmények. — Földtani Közlöny 87, 165-172.

LIFFA A. 1953: Gönc, Fony, Telkibánya és Alsókéked közötti terület földtani újratérképezése. — A Magyar Állami Földtani Intézet Évi Jelentése az 1950. évról, 101-102.

Lőw M. 1908: A rézbányai cerussitek kristálytani viszonyai. — Földtani Közlöny 38, 165-179.

Lőw M. 1925: Ércelőfordulások a Mátrában. — Földtani Közlöny 55, 127-143.

MADERSPACH L. 1876: A telekes-rudabányai vasérc vonulat. — Oesterreichische Zeitschrift für Berg und Hüttenwesen, 72 p.

MAdERSPACH L. 1877: A Pelsöcz-Ardói czink- és gálma fekhelyek. — Földtani Közlöny 7, 121-124.

MAJoros G. 1997: A Mecseki lelőhelyen kívüli uránkutatás Magyarországon. — Földtani Kutatás 34, 15-18.

MARTINY I. 1888: Az Ó-Antaltárna által feltárt ércztelérek Vihnye és Hodrus között. — Földtani Közlöny 18, 467-479.

MEINHARDT V. 1921: Manganerzlager bei Úrkút in Ungarn. — Stahl und Eisen 41/2, 1117-1118.

MÉsZÁRos J. 1983: A szerkezetföldtani vizsgálatok szerepe a bakonyi távlati mangánérckutatásban. — Földtani Közlöny 113, $261-264$.

MiKó L. 1964: A Velencei-hegységi kutatás újabb földtani eredményei. — Földtani Közlöny 94, 66-74.

MolNÁr F. 1994: A Tokaji-hegység Sátoraljaújhely-Rudabányácska és Vágáshuta közötti területének nemesfém-dúsulásait létrehozó hidrotermás folyamatok rekonstrukciója. — Földtani Közlöny 124, 25-42.

MoLNÁR F. 1997: Újabb adatok a Velencei-hegység molibdenitjének genetikájához: ásványtani és folyadékzárvány vizsgálatok a Retezilejtakna ércesedésén. - Földtani Közlöny 127, 1-17.

MoLNÁR F. \& GATTER I. 1994: Magyarországi üledékes és hidrotermás baritkristályok összehasonlító ásványtani-genetikai vizsgálata. — Földtani Közlöny 124, 43-57.

Molnár, F., Zelenka, T., MátyÁs, E., Pécskay, Z., Bajnóczi, B., Kiss, J. \& Horváth, I. 1999: Epithermal mineralization of the Tokaj Mts., Northeast Hungary: Shallow levels of low-sulfidation type systems. — In: Molnár, F., LeXA J. \& HedenQuist J. W. (eds): Epithermal mineralization of the Western Carpathians. Society of Economic Geologists Guidebook Series 31, 109-153.

Molnár, F., Jung, P., KupI, L., Pogány, A., VÁGÓ, E., VikToRIK, O. \& PÉCskAY, Z. 2008: Epithermal zones of the porphyry-skarn-epithermal ore complex at recsk. — In: FöLDESSY J. (ed.): Recsk and Lahóca — Geology of the Paleogene Ore Complex. — Publications of the University of Miskolc, Series A., Mining 73, 101-130.

MolnÁR J. (szerk.) 2014: A Pátka-Szúzvár egykori fluorit-és ércelőfordulásunk újraértékelése. — Milagrossa, Miskolc.

MolnÁr J. \& Morvai G. 1961: Eger környéki és néhány külföldi oligocén mangánérctelep összehasonlítása. — Földtani Közlöny 91, $126-135$.

Morvai L. \& Viola B. 1975: A recski mélyfúrási geofizikai kutatások eredményei. — Földtani Közlöny 105, 733-739.

NAGY B. 1969: Az ólom, cink, molibdén, bárium és fluor területi elterjedésének vizsgálata a Velencei-hegység gránit ásványaiban. — Földtani Közlöny 99, 313-319.

NAGY B. 1970: A magyarországi hidrotermális szfaleritek indiumtartalmának geokémiai vizsgálata. — Földtani Közlöny 100, $285-292$.

NAGY B. 1971: A Mátra-hegységi földtani képződmények áttekintő geokémiai vizsgálata. — Földtani Közlöny 101, 62-68.

NAGY B. 2002: Adatok a Börzsöny hegységi nemesfém-ércesedések és indikációk ásványtani és geokémiai ismereteihez. — Földtani Közlöny 132, 401-421.

NÉmeth, N. \& Hartai, É. (eds) 2009: Telkibánya geology. — Publications of the University of Miskolc Series A, Mining 78, 193 p.

Németh N., Baracza M. K., Kristály F., Móricz F., Pethő G. \& Zajzon N. 2016: Ritkaföldfém- és ritkaelem-dúsulás a Bükk hegység délkeleti részének vulkáni eredetû́ kôzettesteiben. - Földtani Közlöny 146, 11-25.

NoszKy J. \& SiKABONYI L. 1953: Karbonátos mangánüledékek a Bakony hegységben. — Földtani Közlöny 83, 344-359.

ÓDOR L. \& SZEREDAI L. 1964: A velencei-hegységbeli lászlótanyai fluorit ásványtani vizsgálata. — Földtani Közlöny 94, 75-81.

PÁLFY M. 1905: Adatok a verespataki kirnik kőzetének pontosabb ismeretéhez. — Földtani Közlöny 35, 314-308.

PÁlFy M. 1910: A szarvaskői wehrlittömzs. — Földtani Közlöny 40, 480-486. 
PÁLFY M. 1916: Az erupciós kőzetek zöldkövesedése. — Földtani Közlöny 46, 73-85.

PANTó D. 1935: A dunai aranymosás kérdése. - Földtani Közlöny 65, 182-274.

PANTó E. (szerk). 1957: Rudabánya ércbányászata. — Budapest, OMBKE, 423 p.

PANTó G. 1948: A mádi vasércelőfordulás bányageológiai viszonyai. - Jelentés a Jövedéki Mélykutatás 1947/48. évi munkálatairól, 254-257.

PANTÓ G. 1949: A nagybörzsönyi ércelőfordulás. — Földtani Közlöny 79, 421-433.

PANTó G. 1951: Az eruptívumok földtani helyzete Diósgyőr és Bükkszentkereszt között. — Földtani Közlöny 81, 137-145.

PANTÓ G. 1952: Bányaföldtani felvétel Recsk és Parád környékén. — A Magyar Állami Földtani Intézet Évi Jelentése az 1949. évról, 67-75.

PANTó G. 1953: Bányaföldtani felvétel Gyöngyösoroszin. - A Magyar Állami Földtani Intézet Évi Jelentése az, 1950. évról, $155-163$.

PAPP, F. 1932: Über die Andesit- und Dacit-Kontakte im Börzsöny-Gebirge (Ungarn). — Földtani Közlöny 62, 124-129.

PAPP, F. 1933: Über den petrographischen und geologischen Bau der Umgebung von Márianosztra [IV. Taf.] = Márianosztra és Nagyirtáspuszta környékének kőzet- és földtani felépítéséről [IV. tábl.]. — Földtani Közlöny 63, 62-95.

PAPP K. 1908: Almásszelistye érctermő vidéke Hunyad vármegyében. - Földtani Közlöny 38, 294-306.

PAPP K. 1911: A Hunyad vármegyei Godinesd környékének mangántelepei. — Földtani Közlöny 41, 551-564.

PAPP F. \& POJJÁK T. 1948: Jelentés a Keszthely-környéki szulfidos ércek összetételéről, különös tekintettel a piritek és markazitok mennyiségére. - Jelentés a Jövedéki Mélykutatás 1947/48. évi munkálatairól, 104-105.

Polgári, M., SZABó-Drubina, M., \& HeIn, J. R. 2003a: Phosphogenesis in Jurassic black shale-hosted Mn-carbonate deposits, Úrkút and Eplény, Hungary: Investigations on archive sample drillcore Úrkút-136. - Földtani Közlöny 133, 37-48.

Polgári, M., Szabó-Drubina, M., Hein, J. R. \& Szabó, Z., 2003b: Analysis of an archive sample from the carbonatic manganese ore sequence, Eplény, Hungary. — Földtani Közlöny 133, 21-35.

Poros Zs., Molnár F., Koroknai B., Lespinasse, M., Maros Gy. \& BenKó Zs. 2008: Fluidzárványsíkok és repedésrendszerek vizsgálatának alkalmazása granitoid kőzetek repedezettségének fejlődéstörténeti rekonstrukciójában III: A Bátaapáti (Üveghuta) radioaktív hulladéktároló telephely kutatófúrásaiban végzett vizsgálatok eredményei. — Földtani Közlöny 138, 363-384.

PratZer F. 1871: A Selmeczvidéki ércztelérek viszonyai. — Földtani Közlöny 1, 183-191.

RoZlozsNiK P. 1919: A „Macskamező”-típusú vas-mangánércek elterjedése Erdélyben. — Földtani Közlöny 49, 21-43.

SÁMSONi Z. 1966: Néhány magyarországi galenit és szfalerit nyomelem vizsgálata. — Földtani Közlöny 66, 387-402.

SCHEFFER V. 1963: Adatok a Vardaridák és a Bánáti-árok felszínalatti vonulatainak követéséhez a Kárpát-medencékben. — Földtani Közlöny 93, 286-303.

SCHRÉTER Z. 1948a: A Füzérradvány és Gönc közötti terület földtani viszonyai. — Jelentés a Jövedéki Mélykutatás 1947/48. évi munkálatairól, 258-278.

SCHRÉTER Z. 1948b: Adatok a telkibánya vidéki érces terület földtani viszonyaihoz. — Jelentés a Jövedéki Mélykutatás 1947/48. évi munkálatairól, 320-334.

SElmeCZinÉ Antal P. \& Vincze J. 1986: A szénült és ásványosodott növényi maradványok szerepe a mecseki uránércesedésben. — Földtani Közlöny 116, 111-136.

SiDó M. \& SiKABONYI L. 1953: Az úrkúti és eplényi mangánérc-terület mikropaleontológiai kiértékelése. — Földtani Közlöny 83, 401-418.

SiKLÓssy S. 1977: Gyöngyösoroszi és környékének szerkezeti értékelése. — Földtani Közlöny 107, 348-357.

SINGH A. K. 1974: A rózsabányai (Nagybörzsöny) szulfidos ércásványok elektron-mikroszondás vizsgálata. — Földtani Közlöny 104, 318-324.

SiNGH A. K. 1975: A talajgeokémiai vizsgálatok, mint alkalmazható geokémiai kutató-módszer a rózsabányai területen. — Földtani Közlöny 105, 193-207.

STÜRZENBAUM J. 1879: Az ardói czinkércz-fekhely geológiai viszonyairól. — Földtani Közlöny 9, 213-216.

SzABÓ J. 1875a: A trachyt-képlet Szászka környékén. — Földtani Közlöny 5, 72-83.

SZABÓ J. 1875b: Enargit újabb elöjövetele Parádon. — Földtani Közlöny 5, 158-160.

SzABÓ J. 1876: Adatok magyarhoni ásványok újabb előjövetéhez Nagybányán és Rézbányán. — Földtani Közlöny 6, $247-254$.

SzABÓ J. 1877: A Wehrlit Szavaskőról. — Földtani Közlöny 7, 169-181.

SzABÓ J. 1878: Petrographiai s geológiai tanulmányok Selmecz környékéről. —Földtani Közlöny 8, 103-134.

SZABó J. 1891: Mozgások a Selmeczi teléreken geológiai tekintetben. — Földtani Közlöny 21, 161-164.

SZABÓ Z. 1979: A mangánérc távlati terv végrehajtása, a mélyfúrásos és a bányabeli kutatás adatainak egybevetése. — Földtani Közlöny 109, 459-468.

SzABÓ Z. 2006: Bakonyi mangánércek bányászata, Farkas József bányamérnök emlékére. — Mangán Bányászati és Feldolgozó Kft. Úrkút, 655 p.

SZABÓ B., MolNÁr F., BENKó Zs. \& LeSPINASSE, M 2008: Fluidzárványsíkok és repedésrendszerek vizsgálatának alkalmazása granitoid kőzetek repedezettségének fejlődéstörténeti rekonstrukciójában II.: A Mórágyi Gránit repedésrendszerei. — Földtani Közlöny 138, $247-256$.

SZABÓ I. \& VINCZE J. 2002: Bükk hegységi törmelékes perm képződmények földtani, kőzettani vázlata és ércindikációi. — Földtani Közlöny 132, 181-221.

SZABÓ I. \& VINCZE J. 2013: A bükkszentkereszti riolit (kvarcporfír)-tufa Mn-ércesedéssel társult U-Be tartalmú foszfátásványosodása. — Földtani Közlöny 143, 3-28.

SZABÓNÉ Drubina M. 1959a: Az eplényi mangánércelőfordulás kőzettani viszonyai. — A Magyar Állami Földtani Intézet Évi Jelentése az 1955-56. évról, 331-342.

Szabóné Drubina, M. 1959b: Manganese deposits of Hungary. — Economic Geology 54, 1078-1094., http://dx.doi.org/10.2113/ gsecongeo.54.6.1078

SZÁDECZKY G. 1897: Sátoralja-ujhelytől északnyugatra, Ruda-bányácska és Kovácsvágás közé esô terület geológiai és kőzettani tekintetben. - Földtani Közlöny 28, 273-326. 
SZALAY I. 1975: A recski kutatási terület szerkezetkutató geofizikai mérései és azok eredményei. — Földtani Közlöny 105, 724-732.

SZÉKYNÉ FuX V. 1964: Propilitesedés és kálimetaszomatózis tokaji-hegységi vizsgálatok tükrében. — Földtani Közlöny 94, 409-421.

SZÉKYNÉ FuX V. 1966: Ércesedést kísérő agyagásványosodás mélységi övei a Tokaji-hegységben. — Földtani Közlöny 96, 3-12.

SzENTES F. 1948: A kénkovand előfordulások földtani viszonyai a Keszthelyi-hegység környékén. — Jelentés a Jövedéki Mélykutatás 1947/48. évi munkálatairól, 51-103.

SzENTPÉTERI K. \& MoLNÁR F. 2000: Adulár-szericit típusú hidrotermás indikáció ásványtani és genetikai vizsgálata a sárszentmiklósi Szarvas-hegyen. - Földtani Közlöny 130, 1-23.

SZENTPÉTERY I. 1997: A Rudabánya-690. sz. földtani alapfúrás. — Földtani Közlöny 127, 179-198.

SzoKol P. 1896: Veresvíz aranyerei. — Földtani Közlöny 26, 243-246.

SZOLNOKI J. \& BOGNÁR L. 1965: Baktériumok szerepe a szulfidércek oxidációjában. — Földtani Közlöny 95, 86-94.

SZTRÓKAY K. 1941: A mecsek-hegységi magnetit. - Földtani Közlöny 71, 37-50.

TAKÁCS Á. \& MolnáR F. 2011: Az infravörös mikroszkópia alapjai és alkalmazása opak ásványok fluidumzárvány vizsgálatában. — Földtani Közlöny 141, 401-414.

TaKÁcs, Á., MolnÁr, F., Turi, J., Mogessie, A. \& Menzies, J. C. 2017: Ore Mineralogy and Fluid Inclusion Constraints on the Temporal and Spatial Evolution of a High-Sulfidation Epithermal Cu-Au-Ag Deposit in the Recsk Ore Complex, Hungary. — Economic Geology 112, 1441-1460., https://doi.org/10.5382/econgeo.2017.4516

TÉGLÁS G. 1893: A Fejér-Körösvidék jelentősége a rómaiak bánya-administratiojában. — Földtani Közlöny 23, $272-276$.

VADÁsz E. 1953: A bakonyi mangánércképződés földtani dialektikája. — Földtani Közlöny 83, 70-74.

Varga G., Csillagné Teplánszky E., Vargáné Máthé K., Félegyházi Z. 1975: A Mátra hegység földtana. — A Magyar Állami Földtani Intézet Évkönyve 57, 320 p.

VARGÁNÉ MÁTHÉ K. 1961: Kálimetaszomatózis és kálifeldúsulás a Sátoraljaújhely és Vágáshuta közti területen. — Földtani Közlöny 91, 391-396.

VÁRSZEGI K. 1965: Karbonátos rézásvány-előfordulás a mecseki éger-völgy alsótriász rétegeiben. — Földtani Közlöny 95, 437-438.

VINCZE J. 1987: A mecseki perm uránércesedésének vizsgálata modellkísérletekkel. — Földtani Közlöny 117, 347-373.

VinCZE J. \& FAZEKAS V. 1979: A mecseki uránérc ásványtani és paragenetikai kérdései. — Földtani Közlöny 109, 161-198.

VINCZE J. \& FAZEKAS V. 1991: Hidrotermális ércindikációk a Villányi-hegység északi előtere mélyfúrásaiban. — Földtani Közlöny 121, 23 -56.

ViNCZE J., FAZEKAS V. \& KósA L. 1996: A fertőrákosi kristályospala összlet urán-tórium-ritkaföldfém és szulfidos ásványosodásai. — Földtani Közlöny 126, 359-415.

VincZe J., OpaUSZKY I. \& HoRváth I. 1970: 32S/34S-izotópok eloszlása és szerepe a mecseki uránércesedésben. — Földtani Közlöny $100,55-65$.

VincZE J. \& SoMOGYI J. 1984a: A mecseki felsőpermi homokkő uránércesedési formaelemei és fácieskapcsolataik (I. rész). — Földtani Közlöny 114, 189-213.

VINCZE J. \& SOMOGYI J. 1984b: A mecseki felsőpermi homokkő uránércesedési formaelemei és fácieskapcsolataik (II. rész). — Földtani Közlöny 114, 309-319.

Vincze J., G. Sólymos K., Ditróı-PusKás Z. \& Kósa L. 2011: Mikroteléres, -eres uránérc a nyugat-mecseki gránitban. — Földtani Közlöny 141, 325-339.

VIRÁGH K. 1979: A mecseki érclelőhely földtani, teleptani adottságai és kutatáselméleti vonatkozásai._Földtani Közlöny 109, 366-373.

VIRÁGH K. \& SzOLNOKI J. 1970: Baktériumok szerepe a mecseki uránérc keletkezésében és későbbi áthalmozásában. —Földtani Közlöny 100, 43-54.

VIRÁGH K. \& VINCZE J. 1967: A mecseki uránérclelóhely képződésének sajátosságai. — Földtani Közlöny 97, 39-59.

VITÁLIS S. 1926: Mátrabánya arany-, ezüst- és rézércbányászata. - Földtani Közlöny 56, 30-40.

WéBER B. 1962: Thorium és ritkaföld indikációk a Budai-hegységben. - Földtani Közlöny 92, 455-457.

WÉBER B. 1975: Az urán és tórium eloszlása az Északi-középhegység földtani képződményeiben légi-gammaspektrometriai mérések alapján. - Földtani Közlöny 105, 309-319.

WÉBER B. 1997: A Mecsek hegységi uránérclelőhely kutatástörténete. - Földtani Kutatás 34, 11-15.

WÉBER B. \& GÉRESI G. 1970: A kálium eloszlása a Mátra-hegységben légi-gammaspektrometriai felvétel alapján. — Földtani Közlöny 100, 77-87.

WÉBER B. \& GÉRESI G. 1972a: A kálium eloszlása a Tokaji-hegységben légi-gammaspektrometriai felvétel alapján. — Földtani Közlöny 102, 151-162.

WéBER B., NAGY L. \& GÉRESI G. 1972b: A kálium eloszlása a Börzsöny-hegységben légi-gammaspektrometriai felvétel alapján. — Földtani Közlöny 102, 136-150.

WINKLER B. 1871: A verespataki aranybányászat viszonyai. — Földtani Közlöny 1, 64-70.

ZeLENKA T. 1975: A recski mélyszinti színesfém ércelőfordulás szerkezeti-magmaföldtani helyzete. — Földtani Közlöny 105, 582-597.

ZeLENKA T. 1977: A Recsk és Parádsasvár környéki kutatások szerkezetföldtani eredményei. — Földtani Közlöny 107, 358-367.

ZelenKA T. \& MARKó B. 1979: A recski mélyszinti kutatóakna, a vágathajtás és a megelőzô mélyfúrásos kutatás összehasonlító tapasztalatai. — Földtani Közlöny 109, 469-477.

Kézirat beérkezett: 2020. 03. 12. 